\title{
The relationship between pension funds and the stock market: Does the aging population of Europe affect it?
}

\author{
Mercedes Alda \\ University of Zaragoza, Economics and Business Faculty, C/Gran Via, 2, C.P. 50005, Zaragoza, Spain
}

\section{A R T I C L E IN F O}

Article history:

Received 30 June 2016

Received in revised form 27 October 2016

Accepted 30 December 2016

Available online xxx

JEL classification:

G10

G14

G23

Keywords:

Capitalization

Development

Efficiency

Pension funds

Stock market

\section{A B S T R A C T}

In recent decades, pension fund investment has increased rapidly because of population aging and growing doubts about the viability of western public pension systems. As a result, pension funds have become dominant in stock markets. This paper examines the influence of the pension fund assets invested in equities on stock market development and the market efficiency of 13 European countries, from 1999 to 2014. Our results vary by country, by pension model and among the one-model countries. Nevertheless, revealing a concern about saving for retirement. Finally, our efficiency analysis reveals that the influence of pension funds varies over time and across markets, due to arbitrage opportunities that provoke adaptive managerial strategies.

CC 2016 Published by Elsevier Ltd.

\section{Introduction}

Pension funds have become primary investment vehicles in recent decades (the worldwide assets exceeded \$25.2 trillion in 2014-OECD, 2015). This remarkable development is a consequence of progressive population aging and doubts about the viability of pay-as-go public pension systems in many western countries, especially in Europe.

As institutional investors, pension funds are market players that have a distinct influence on stock markets (Vo, 2016). The existing literature demonstrates that pension funds enhance financial development, achieve more efficient investments (Davis, 1995; Meng \& Pfau, 2010; Rocholl \& Niggemann, 2010; Vittas, 1996) and stimulate private and national savings (Kohl \& O'Brien, 1998; Poterba, 1998; Reisen \& Bailliu, 1997; Rezk, Irace, \& Ricca, 2009; Schmidt-Hebbel, 1999). Some authors claim that financial markets are dependent on pension fund investments, and pension provisions are contingent to market performance in certain countries (Clark, 2000). Nevertheless, the investment practices of pension professionals have important repercussions for both global stock markets (Badrinath \& Wahal, 2002; Brown, Wei, \& Wermers, 2007; Lakonishok, Shleifer, \& Vishny, 1992; Wermers, 1999) and future retirement income.

Understanding the influence of pension funds in the stock market is important from a theoretical and practical point of view. There is a

Email address: malda@unizar.es (M. Alda) substantial literature investigating the impact of institutional investors on stock markets (Catalan, Impavido, \& Musalem, 2000; Davis \& Hu, 2004; Impavido, Musalem, \& Tressel, 2003; Zeng, 2016), although works studying the impact of pension funds in isolation are limited. Walker and Lefort (2002) find a positive link between pension reforms that enhance pension funds and capital market development. Davis (2004) finds a strong correlation between stock market capitalization and the size of the pension fund market. Meng and Pfau (2010) find that pension assets improve market capitalization and liquidity in countries with high levels of financial development. In contrast, $\mathrm{Hu}$ (2012) studies Asian occupational pension funds and finds that pension funds only have a positive influence on the market capitalization of the least developed economies.

Some of these prior works differentiate between developed and emerging economies, but ignore the country-pension model, which may be responsible for the variety of results. Indeed, pension fund investment decisions are greatly influenced by the expected public pension income, which depends on the country-specific welfare model adopted. Attending to the social policy and pension regulation, we find four different welfare models in Europe (Anglo-Saxon, Continental, Mediterranean, and Nordic). The distinctive features of each pension system have given rise to substantial differences in the complementary pension system size (Casalegno, 2006; Ferrera, 2013; Sapir, 2006; Sengoku, 2004). In this work, we study thirteen countries, covering these four pension models, and we argue that the pension fund assets invested in equities have a lesser influence in stock markets when public pensions are more generous. However, the re- 
cent financial crisis and the pronounced population aging have revealed major concerns about the sustainability of those systems with larger public pensions. In this scenario, many countries have reformed their public pension systems and emphasized the need for individuals to save for retirement and complement the public pension provisions. These strategies may encourage citizens to save more for retirement, activating and enhancing pension fund investment and, therefore, increasing its impact on stock markets.

The aging of the population is an important demographic shift that may affect stock markets; as a matter of fact, the recent global economic crisis has proven that stock markets can be seriously affected by change (Vo, 2016), although the aging effect on stock markets is not clear (Brooks, 2002; Davis \& Li, 2003; Poterba, 2004). Pension funds are long-term savings vehicles; however, the aging trend may have a negative impact on stock markets whether elderly savers tend to be more conservative (Bergantino, 1998; Goyal, 2004; Poterba, 1998). The latter aspect has not been previously studied in the financial literature, so we first examine the influence of pension funds on thirteen European stock markets, in the context of population aging.

Pension fund investment may also affect stock market efficiency, especially when pension funds achieve considerable stock market control, influencing stock prices. The Efficient Market Hypothesis (EMH), developed by Fama (1970), presents the concept of fully efficient markets; nonetheless, several studies find that stock returns do not follow random walks (Brock, Lakonishok, \& LeBaron, 1992; Fama \& French, 1988; Jegadeesh \& Titman, 1993; Lo \& MacKinlay, 1988). To explain this lack of efficiency, the behavioural finance paradigm of Adaptive Market Hypothesis (AMH) introduces the idea of varying efficiency over time (Lo, 2004). Lo (2005) argues that individuals act in their own interest, make mistakes, and learn from their mistakes. This dynamic produces market evolution, with arbitrage opportunities appearing sporadically. These opportunities, once they are exploited, disappear, but new opportunities emerge, implying complex market dynamics.

Multiple agents are part of this market dynamic, especially institutional investors. Certain works support the notion that institutional investors help to achieve market efficiency (Barber, Lee, Liu, \& Odean, 2009; Boehmer \& Kelley, 2009; Griffin, Harris, \& Topaloglu, 2003); however, other authors find the opposite result (Brunnermeier \& Nagel, 2004; Dow \& Gorton, 1997; Zeng, 2016). The long-term nature of pension funds may improve market efficiency, but managers may lose the incentive to apply long-term strategies because it takes longer to reveal their private information than allowed for by their tenure (Goldman \& Slezak, 2003). Additionally, periodic performance scrutiny, competition among managers (Abreu \& Brunnermeier, 2002, 2003), and concerns about future careers (Hong, Scheinkman, \& Xiong, 2008), may all force managers to invest in overvalued assets with high past returns, producing prolonged stock mispricing.

The ambiguous effect of professional management on market efficiency may be explained by the AMH perspective. Just as market efficiency may vary over time, so the pension fund influence on market efficiency may also fluctuate. The uncertainty of the pension fund influence on market efficiency lends support to our study, which, to the best of our knowledge, is the first attempt to analyze this aspect.

The motivation of this work is twofold. First, the paper sheds light on the pension fund effect in the stock market development of thirteen European countries with distinctive pension systems. A better understanding of this relationship is important for governments in their decisions to carry out pension reforms that enhance the sustainability of pay-as-you-go (PAYG) systems and economic growth. Second, we examine how pension funds affect market efficiency. The latter analysis will provide assistance to market regulators in the supervision of pension fund managers.

Our results show a direct relationship between equity pension fund investment and market development; nonetheless, this relation is not significant in some countries. We find diverse results among the different-model countries, and among the countries with a common model, supporting the great diversity of European pension systems. Contrary to our expectations, countries with more generous public pensions (Mediterranean system) do not impact stock market development to a lesser extent. This result may lay on the fact that the generous public pensions of the Mediterranean welfare system are causing financing problems and increasing doubts about the sustainability of the system. Consequently, private pension fund industries have remarkably increased over last years. On the other hand, we find greater pension fund influence on the stock market when the population increases, even the elderly population. This fact reveals that population is concern about saving with increasing aging, and the elderly population continues saving on equities after retirement, despite their conservative risk profile. Finally, the efficiency analysis demonstrates varying market efficiency over time and across markets. Pension funds also influence market efficiency differently over time and across countries, due to the existence of arbitrage opportunities and managerial strategies that adapt to market circumstances.

The rest of the paper is organized as follows. Section 2 describes the European pension models of the countries analyzed, and the data sample. Section 3 presents our methodology. The empirical results and discussion are collected in Sections 4, and 5 concludes.

\section{The European pension fund markets and data description}

In this section, we first briefly introduce the different European pension models and the characteristics of the pension fund markets studied. We then describe the data sources and variables.

\subsection{The European pension fund industry}

We study the influence of pension fund assets invested in equities on the stock markets of thirteen European countries. The countries studied are: Austria, Belgium, Denmark, Finland, Germany, Ireland, Italy, the Netherlands, Norway, Portugal, Spain, Sweden and the United Kingdom. These countries do not all have identical pension systems, but they present common characteristics that allow to classify them into several groups.

There are several ways to classify pension systems. The most accepted classification by academics refers to the four welfare or social models established in Europe after the Second World War: Anglo-Saxon, Continental, Mediterranean and Nordic (Bertola, Boeri, \& Nicoletti, 2001; Boeri, 2002; Casalegno, 2006; Ferrera, 1998; Ferrera, 2013; Sapir, 2006; Sengoku, 2004), attending to the geographical location. In this work we refer to this classification because it represents the social policy models that established the national public pension systems and, by extension, conditioned the characteristics of the private pension fund industries. Nevertheless, as Sapir (2006) remarks, it is worth noting that there are wide differences both between the models and within each of them.

The Anglo-Saxon model is implemented in Ireland and the United Kingdom (UK), and is characterized by providing social benefits to all in need, but the social funds are accumulated by the citizens themselves (Popova \& Kozhevnikova, 2013). The greater fund portion is for the working-age population, while pensioners receive a minor part, with the replacement rates being lower for higher earners than for lower earners (Disney \& Johnson, 2001). In this scenario, public 
pensions are not large, and private pension funds are well-developed. The UK pension system is the most distinctive of this model, in which private pensions support an important part of pensioner income; for example, for the top quintile of pensioners, state pensions only accounted for one quarter of total income, according to the European Commission (2001).

The Continental model includes Austria, Belgium, France, Germany and Luxembourg. This model is between the Anglo-Saxon and Nordic model, characterized by high expenses for social support, moderate re-distribution, and larger public pension systems. Nonetheless, social support is given to those who have already been represented on the labour market, and depends on the social accumulation of each person, so public pension benefits are often linked to the fulfillment of certain conditions (Popova \& Kozhevnikova, 2013), although replacement rates are high at all income levels and, hence, private pension investment is smaller.

The Mediterranean model, represented by Italy, Greece, Spain, and Portugal, offers high social support, but redistribution of wealth is low, presenting high unemployment and poverty levels (Popova \& Kozhevnikova, 2013). The social spending is concentrated on old-age pensions. State-pensions are generous and early retirement pensions are common (Sapir, 2006); as a result, pension funds appeared later than in other countries. Nonetheless, due to doubts concerning the viability of public pensions and favorable tax treatments, private pensions have experienced notable development in recent decades, especially in Italy and Spain.

The Nordic model includes Denmark, Finland, the Netherlands, Norway, and Sweden (Casalegno, 2006; Ferrera, 2013; Norden, 2013). Although disparities between countries in this model are considerable, they include statutory minimum basic protection and the possibility of receiving a pension that reflects the individual's historical salary. Replacement rates in pensions are higher than in the Anglo-Saxon countries, but lower than the Continental and Mediterranean rates. Pension benefits are closely tied to contributions; that is, pensions are calculated on an actuarial basis, received by taxpayers rather than non-taxpayers. Initially, Nordic pension systems offered small pensions, but several PAYG systems were transformed into mixed pension systems in certain countries, such as Sweden, in which a notional defined contribution scheme was established. In this system, workers continue to pay for the pay-as-you-go pensions, but a portion of their contributions accumulates in notional accounts, building up a capital for retirement. These reforms provoked unevenly development of private pension funds, being important saving vehicles only in certain countries, such as the Netherlands.

Table 1 collects the private pension fund investment in the countries studied in 2014 and shows the total investment in pension funds (USD million), the pension fund investment in equities (USD million), the weight of the pension fund investment in equities over the total pension fund assets, and the weight of pension fund assets over the GDP, in 2014

We observe a remarkable pension fund investment in the United Kingdom and the Netherlands, with more than $\$ 2.6$ trillion and $\$ 1.2$ trillion, respectively. This investment represents $96.01 \%$ and $159.32 \%$ of GDP, respectively. Pension funds in Ireland, Finland, and Denmark also represent an important weight of GDP (58.14\%, 51.05\% and $48.59 \%$, respectively). The total investment is also notable in Germany, Italy and Spain (\$236, \$130 and \$121 billion), but the weight on their economies is modest $(6.7 \%, 6.66 \%$ and $9.46 \%$ of GDP). The pension fund investment in equities is moderate, $16.87 \%$ on average. Ireland, Austria, and Finland each have over $32 \%$ of assets invested in equities, while Belgium and Germany only invest
Table 1

Pension fund investment by country in 2014

Table 1 shows the total investment in pension funds (USD million), the pension fund assets invested in equities (USD million), the pension fund share in equities (percentage of pension fund assets invested in equities over the total pension fund assets), and the total pension fund assets over the GDP, in percentage, in 2014 for the countries studied (Ireland, the UK, Austria, Belgium, Germany, Italy, Portugal, Spain, Denmark, Finland, the Netherlands, Norway, and Sweden).

\begin{tabular}{lllll}
\hline & $\begin{array}{l}\text { Total PF assets } \\
\text { (USD million) }\end{array}$ & $\begin{array}{l}\text { Assets in equities } \\
\text { (USD million) }\end{array}$ & $\begin{array}{l}\text { Equity PF/ } \\
\text { total assets }\end{array}$ & $\begin{array}{l}\text { PF assets/ } \\
\text { GDP }\end{array}$ \\
\hline Ireland & $130,880.0$ & $46,188.7$ & $35.29 \%$ & $58.14 \%$ \\
UK & $2,684,613.5$ & $461,845.1$ & $17.20 \%$ & $96.01 \%$ \\
Austria & $23,275.7$ & 7587.2 & $32.60 \%$ & $5.83 \%$ \\
Belgium & $27,560.9$ & 2195.1 & $7.96 \%$ & $5.65 \%$ \\
Germany & $236,203.9$ & 351.7 & $0.15 \%$ & $6.70 \%$ \\
Italy & $130,657.9$ & $17,700.7$ & $13.55 \%$ & $6.66 \%$ \\
Portugal & $21,254.3$ & 1966.0 & $9.25 \%$ & $8.77 \%$ \\
Spain & $121,585.0$ & $11,344.2$ & $9.33 \%$ & $9.46 \%$ \\
Denmark & $152,348.5$ & $23,395.4$ & $15.36 \%$ & $48.59 \%$ \\
Finland & $126,446.1$ & $49,115.2$ & $38.84 \%$ & $51.05 \%$ \\
Netherlands & $1,282,009.5$ & $148,301.1$ & $11.57 \%$ & $159.32 \%$ \\
Norway & $37,380.4$ & 5701.9 & $15.25 \%$ & $8.81 \%$ \\
Sweden & $47,035.8$ & 6079.3 & $12.92 \%$ & $9.30 \%$ \\
Average & $386,250.1$ & $60,136.3$ & $16.87 \%$ & $36.48 \%$ \\
\hline Source: OEC & pensin & &
\end{tabular}

Source: OECD pension statistics database (http://stats.oecd.org/).

$7.96 \%$ and $0.15 \%$ of their assets in equities. These figures demonstrate the conservative character of pension funds.

Actually, pension fund investment in equities has declined in the last ten years (OECD, 2015). Specifically, the investment in equities of the countries studied (not reported) from 1999 to 2014 reveals that pension funds adjust their portfolios according to financial market conditions, increasing from $22.9 \%$ in 2002 to $29.9 \%$ in 2006 , and decreasing to $11.39 \%$ from then until 2011 . Since 2011 , the investment in equities has recovered to $16.87 \%$ in 2014 . This lesser significance of equities in pension fund portfolios may affect our results, and we may expect a reduced pension fund influence on stock markets than was seen in prior works, which included the total pension fund assets.

Table 1 also reveals common characteristics of the countries with the same pension model. The Anglo-Saxon countries (Ireland and the UK) possess developed pension fund industries, a consequence of limited public pensions. Smaller pension fund weights are found in economies with Continental (Austria, Belgium, Germany) and Mediterranean models (Italy, Portugal, Spain), in which public pension are more generous. The Nordic countries (Denmark, Finland, the Netherlands, Norway and Sweden) are in a middle position, with a considerable pension fund investment ( $55 \%$ of GDP, on average). With regard to the investment in equities, it predominates in the Anglo-Saxon and Nordic economies (26\% and $18 \%$ on average, respectively).

\subsection{Data sources and variables}

Our data is collected from several sources. The total pension fund investment and the pension fund assets invested in equities by country are obtained on an annual basis from the OECD pension statistics database. ${ }^{1}$ The information about pension fund investment in equities is very limited before 1999, which is why we restrict our sample period to 1999-2014. The country MSCI market indices are obtained from Datastream, on a daily basis, to capture the maximum market (MSCI country indices capture about $85 \%$ of market constituents, ac-

${ }^{1}$ OECD pension statistics database: http://www.oecd-ilibrary.org/ finance-and-investment/data/oecd-pensions-statistics_pension-data-en 
cording to $\mathrm{MSCI}^{2}$ ). The market capitalization, ${ }^{3}$ the market capitalization over GDP, the GDP, the gross domestic income (GDI), the public debt, the public debt over the GDP, the 15-64-year-old population ratio, the over- 65 population ratio, the age dependency rate for older individuals (percentage of older people over working-age population) are from the World Development Indicators database of the World Bank, ${ }^{4}$ in annual basis. Finally, the $65-69,70-74,75-79,80-85$ and over-85 population ratios are obtained from Eurostat database. ${ }^{5}$

In the first part of our study, the independent variable of our models is the market capitalization over GDP, as being representative of market development (Demirguc-Kunt \& Levine, 1996; Levine \& Zervos, 1998; Meng \& Pfau, 2010). The explanatory variable capturing the effect of pension fund investment in equities on stock market development is the ratio between the pension fund assets invested in equities and the total pension fund investment in each country (Thomas, Spataro, \& Mathew, 2014). As control variables, we include three market and two economic variables. The market variables represent different market dimensions: the market return, the market volatility, and the market flows. The market return captures the performance of the market, which is calculated annually from the daily market index prices. The market volatility captures the impact of the market fluctuation on stock market development (Thomas et al., 2014). Market volatility is measured as the annual risk of the daily market return. The market flows variable is a proxy for the market growth in two periods. This variable is defined as the net growth, taking into account price evolution (return): $\left[\mathrm{Mc}_{\mathrm{i}, \mathrm{t}}-\mathrm{Mc}_{\mathrm{i}, \mathrm{t}-1} *\left(1+\mathrm{R}_{\mathrm{i}, \mathrm{t}}\right)\right] / \mathrm{Mc}_{\mathrm{i}, \mathrm{t}-1}$; where $\mathrm{Mc}_{\mathrm{i}, \mathrm{t}}$ is the market capitalization in period $t$, and $\mathrm{R}_{\mathrm{i}, \mathrm{t}}$ is the market return in $t$. The economic variables are: the gross domestic income (GDI) over GDP and the ratio of public debt to GDP. The GDI over GDP represents the economic country development based on expenditure, and the public debt over GDP is a measure of fiscal sustainability of the country (Thomas et al., 2014).

To ascertain the influence of pension funds on stock markets according to the aging, we include three demographic variables in the second part of our analysis. The ratio of the population between 15 and 64 years is the percentage of the total population that is in the 15 to 64 age group. The ratio of the population over age 65 is the percentage of the total population that is in that age group. The age dependency ratio for older individuals is the ratio of older dependents (over age 64) to the working-age population (ages 15-64).

Table 2 shows the main characteristics of the data sample and collects the annual average of the variables (market capitalization over GDP, market capitalization, GDP, market return, market volatility, market flows, gross domestic income (GDI) over GDP, public debt over GDP, pension-fund share invested in equities, population ratio from 15 to 64, population ratio over 65 , and dependency ratio of older people) for all countries studied, from 1999 to 2014.

Table 2 shows the considerable importance of the stock market on economies (average market capitalization over GDP-Mc gdp-of $79.5 \%)$; especially in Denmark $(216.5 \%)$, the Netherlands $(116 \%)$, the UK (109.2\%), and Spain (94.3\%). On the other hand, Austria presents a small market, compared to economic growth (27.7\%). The average market return from 1999 to 2014 is $5.9 \%$, and only Portugal

\footnotetext{
2 MSCI: www.msci.com

${ }^{3}$ The market capitalization provided by the World Bank is the share price times the number of shares outstanding (including their several classes) for listed domestic companies, and excludes the investment funds, unit trusts, and companies whose only business goal is to hold shares of other listed companies.

${ }^{4}$ World development indicators database: http://data.worldbank.org/data-catalog/ world-development-indicators

${ }^{5}$ http://ec.europa.eu/eurostat/data/database
}

presents a negative return $(0.4 \%)$ in this period. The market volatility does not reveal important discrepancies among countries $(0.016$ on average), although it is higher (0.021) in Finland. The market flows reveal an average market growth of $12.8 \%$ from 1999 to 2014 . Finland is the only country with a negative stock market growth during the period studied $(-0.9 \%)$. The highest GDI over GDP is found in the UK (0.704), while the lowest belongs to Norway (0.593). The largest public debt over GDP corresponds to Portugal (1.1), in which the public debt overcomes the GDP, and the lowest public debt to GDP ratio belongs to Denmark (0.3). The average portion of pension assets invested in equities is around $21 \%$. This portion is above $30 \%$ in the UK, Finland, and the Netherlands, while it only represents $9.7 \%, 0.5 \%$, and $9.7 \%$ in Belgium, Germany, and Italy, respectively. The ratios of population from 15 to 64 and over- 65 years are similar in all countries, rounding $66 \%$ and $16 \%$, respectively. Ireland and the UK have the highest and lowest population aged between 15 and 64. On the other hand, Portugal and Norway have the most and least elderly populations, respectively. The dependency ratio of older people is $24.7 \%$, on average, which shows greater aging than the elderly population ratio because it is calculated over the working-age population, and shows more accurately the burden supported by the workforce to pay public pensions.

Although Table 2 does not show large dissimilarities between the country-market volatilities, we examine annual volatility in order to detect possible market return heteroskedasticity. Table 3 presents the annual standard deviation of the daily market return by country from 1999 to 2014, showing different annual return volatility, within and among countries, and revealing the heteroskedasticity of the return series. We also observe cyclical patterns. Volatility is higher during crisis periods (2000-2002 and 2007-2011) than in expansion periods. The heteroskedasticity feature will be taken into account when analyzing market efficiency.

The correlation between the variables used in the study is analyzed in Table 4. This table shows the existence of a relation between the independent variables (Mc_gdp or Mc) and the other variables. Consequently, the variables to be included in the different models are relevant. The high correlation between the market flows and the market return $(96 \%)$ lets us not to include the market flows variable in the models ${ }^{6}$ to avoid collinearity problems. The market volatility and the public debt over GDP present an inverse relation with the market growth (Mc_gdp and Mc), showing that higher volatility and public debt contract the market.

We note that the demographic variables will not be included in isolation, and the interactive PF-share-demographic variables $(\mathrm{PF} *$ pop15-64, $\mathrm{PF} *$ popu $+65, \mathrm{PF} *$ dep) will be used separately in different models. These three variables present positive correlations with Mc gdp. The correlations between the PF-share variable and the interactive pension-demographics variables are higher than $90 \%$; nonetheless, we do not include any of these variables simultaneously in a model, avoiding multicollinearity problems. The over-65-population ratio and the old dependency ratio present an inverse relation with Mc_gdp; however, the PF-share presents a positive correlation with both the over-65-population $(8.1 \%)$ and the dependency $(4.6 \%)$ ratios, so the interaction of these demographic variables with the PF-share produces variables positively correlated with the Mc_gdp. This might show elevated investment in equity pension funds with aging due to higher doubts about public pension viability and the low rate of fixed income assets. The remaining correlations are not higher

\footnotetext{
${ }^{6}$ We have also estimated the different models with the market flows variable, but this variable is not significant.
} 
Table 2

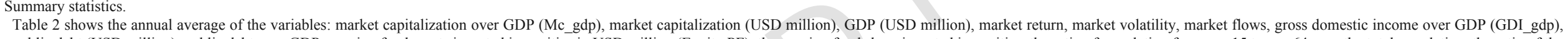

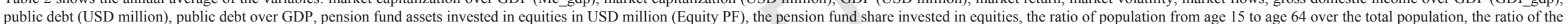

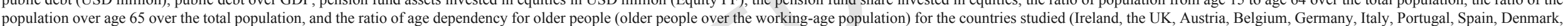
population over age 65 over the total population, and the ratio of age
Finland, the Netherlands, Norway and Sweden) from 1999 to 2014.

\begin{tabular}{|c|c|c|c|c|c|c|c|c|c|c|c|c|c|c|}
\hline & Mc_gdp & Mc & GDP & $\begin{array}{l}\text { Market } \\
\text { return }\end{array}$ & $\begin{array}{l}\text { Market } \\
\text { volatility }\end{array}$ & $\begin{array}{l}\text { Market } \\
\text { flows }\end{array}$ & $\begin{array}{r}\text { GDI } \\
\text { gdp }\end{array}$ & $\begin{array}{l}\text { Public } \\
\text { debt }\end{array}$ & $\begin{array}{l}\text { Public } \\
\text { debt_gdp }\end{array}$ & Equity PF & $\begin{array}{l}\text { PF share } \\
\text { equities }\end{array}$ & Population 15-64 ratio & Population $>65$ ratio & Ratio old dependency \\
\hline All & 0.795 & $6.9 * 10^{5}$ & $8.7 * 10^{5}$ & 0.059 & 0.016 & 0.128 & 0.649 & $4.85 * 10^{5}$ & 0.558 & $6.9 * 10^{4}$ & 0.211 & 0.666 & 0.164 & 0.247 \\
\hline Ireland & 0.846 & $1.75 * 10^{5}$ & $2.08 * 10^{5}$ & 0.003 & 0.016 & 0.121 & 0.598 & $9.46 * 10^{4}$ & 0.455 & $5.22 * 10^{4}$ & 0.620 & 0.684 & 0.170 & 0.249 \\
\hline UK & 1.092 & $2.62 * 10^{6}$ & $2.40 * 10^{6}$ & 0.029 & 0.013 & 0.058 & 0.704 & $1.14 * 10^{6}$ & 0.475 & $5.27 * 10^{5}$ & 0.315 & 0.648 & 0.179 & 0.276 \\
\hline Austria & 0.277 & $9.01 * 10^{4}$ & $3.21 * 10^{5}$ & 0.064 & 0.016 & 0.229 & 0.668 & $2.14 * 10^{5}$ & 0.666 & $3.31 * 10^{3}$ & 0.190 & 0.677 & 0.168 & 0.248 \\
\hline Belgium & 0.647 & $2.54 * 10^{5}$ & $3.93 * 10^{5}$ & 0.055 & 0.014 & 0.160 & 0.653 & $3.60 * 10^{5}$ & 0.917 & $1.74 * 10^{3}$ & 0.097 & 0.657 & 0.172 & 0.262 \\
\hline Germany & 0.482 & $1.42 * 10^{6}$ & $2.97 * 10^{6}$ & 0.054 & 0.016 & 0.106 & 0.654 & $1.26 * 10^{6}$ & 0.425 & $5.14 * 10^{2}$ & 0.005 & 0.658 & 0.160 & 0.243 \\
\hline Italy & 0.836 & $1.50 * 10^{6}$ & $1.81 * 10^{6}$ & 0.010 & 0.015 & 0.007 & 0.671 & $8.34 * 10^{5}$ & 0.461 & $7.94 * 10^{3}$ & 0.097 & 0.663 & 0.166 & 0.250 \\
\hline Portugal & 0.383 & $7.48 * 10^{4}$ & $1.96 * 10^{5}$ & -0.004 & 0.013 & 0.042 & 0.623 & $2.18 * 10^{5}$ & 1.114 & $3.93 * 10^{3}$ & 0.184 & 0.661 & 0.198 & 0.299 \\
\hline Spain & 0.943 & $1.05 * 10^{6}$ & $1.14 * 10^{6}$ & 0.060 & 0.016 & 0.155 & 0.610 & $5.83 * 10^{5}$ & 0.511 & $1.23 * 10^{4}$ & 0.137 & 0.673 & 0.149 & 0.221 \\
\hline Denmark & 2.165 & $5.65 * 10^{5}$ & $2.61 * 10^{5}$ & 0.130 & 0.014 & 0.232 & 0.665 & $7.83 * 10^{4}$ & 0.300 & $2.10 * 10^{4}$ & 0.211 & 0.677 & 0.163 & 0.240 \\
\hline Finland & 0.463 & $9.35 * 10^{4}$ & $2.04 * 10^{5}$ & 0.090 & 0.021 & -0.009 & 0.684 & $8.85 * 10^{4}$ & 0.434 & $5.11 * 10^{4}$ & 0.364 & 0.668 & 0.190 & 0.285 \\
\hline Netherlands & 1.160 & $7.91 * 10^{5}$ & $6.91 * 10^{5}$ & 0.044 & 0.014 & 0.088 & 0.686 & $3.83 * 10^{5}$ & 0.554 & $2.32 * 10^{5}$ & 0.317 & 0.656 & 0.162 & 0.247 \\
\hline Norway & 0.531 & $1.63 * 10^{5}$ & $3.11 * 10^{5}$ & 0.115 & 0.017 & 0.269 & 0.593 & $1.60 * 10^{5}$ & 0.515 & $5.01 * 10^{3}$ & 0.202 & 0.681 & 0.110 & 0.162 \\
\hline Sweden & 0.515 & $2.05 * 10^{5}$ & $3.94 * 10^{5}$ & 0.117 & 0.018 & 0.194 & 0.619 & $1.30 * 10^{5}$ & 0.330 & $6.93 * 10^{3}$ & 0.206 & 0.657 & 0.151 & 0.230 \\
\hline
\end{tabular}


Table 3

Standard deviation of daily return.

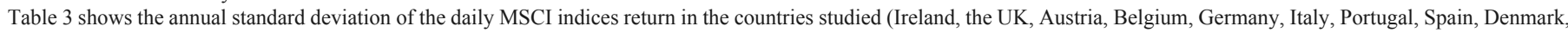
Finland, the Netherlands, Norway and Sweden) from 1999 to 2014.

\begin{tabular}{|c|c|c|c|c|c|c|c|c|c|c|c|c|c|}
\hline & Ireland & UK & Austria & Belgium & Germany & Italy & Portugal & Spain & Denmark & Finland & Netherlands & Norway & Sweden \\
\hline 1999 & 0.011 & 0.010 & 0.010 & 0.012 & 0.013 & 0.011 & 0.010 & 0.012 & 0.011 & 0.022 & 0.011 & 0.013 & 0.014 \\
\hline 2000 & 0.013 & 0.012 & 0.012 & 0.015 & 0.017 & 0.015 & 0.014 & 0.016 & 0.015 & 0.040 & 0.012 & 0.012 & 0.023 \\
\hline 2001 & 0.014 & 0.013 & 0.013 & 0.012 & 0.017 & 0.015 & 0.013 & 0.017 & 0.013 & 0.038 & 0.016 & 0.014 & 0.026 \\
\hline 2002 & 0.016 & 0.015 & 0.011 & 0.018 & 0.022 & 0.015 & 0.013 & 0.019 & 0.015 & 0.028 & 0.021 & 0.014 & 0.021 \\
\hline 2003 & 0.011 & 0.011 & 0.009 & 0.014 & 0.016 & 0.010 & 0.009 & 0.011 & 0.009 & 0.020 & 0.014 & 0.011 & 0.012 \\
\hline 2004 & 0.010 & 0.008 & 0.010 & 0.009 & 0.010 & 0.008 & 0.009 & 0.010 & 0.009 & 0.018 & 0.009 & 0.012 & 0.012 \\
\hline 2005 & 0.009 & 0.007 & 0.009 & 0.007 & 0.008 & 0.007 & 0.008 & 0.008 & 0.009 & 0.011 & 0.008 & 0.012 & 0.009 \\
\hline 2006 & 0.012 & 0.009 & 0.012 & 0.010 & 0.011 & 0.009 & 0.008 & 0.010 & 0.011 & 0.014 & 0.011 & 0.018 & 0.014 \\
\hline 2007 & 0.016 & 0.012 & 0.014 & 0.013 & 0.011 & 0.011 & 0.010 & 0.012 & 0.012 & 0.015 & 0.011 & 0.017 & 0.016 \\
\hline 2008 & 0.036 & 0.026 & 0.033 & 0.029 & 0.024 & 0.025 & 0.023 & 0.027 & 0.026 & 0.029 & 0.024 & 0.037 & 0.029 \\
\hline 2009 & 0.027 & 0.019 & 0.028 & 0.019 & 0.021 & 0.022 & 0.016 & 0.020 & 0.019 & 0.025 & 0.019 & 0.028 & 0.028 \\
\hline 2010 & 0.024 & 0.014 & 0.020 & 0.016 & 0.016 & 0.019 & 0.017 & 0.023 & 0.016 & 0.018 & 0.016 & 0.021 & 0.019 \\
\hline 2011 & 0.021 & 0.016 & 0.023 & 0.017 & 0.022 & 0.025 & 0.018 & 0.023 & 0.017 & 0.023 & 0.019 & 0.022 & 0.024 \\
\hline 2012 & 0.016 & 0.012 & 0.019 & 0.014 & 0.016 & 0.021 & 0.016 & 0.022 & 0.013 & 0.019 & 0.014 & 0.016 & 0.017 \\
\hline 2013 & 0.012 & 0.008 & 0.012 & 0.013 & 0.011 & 0.015 & 0.013 & 0.014 & 0.010 & 0.012 & 0.010 & 0.011 & 0.012 \\
\hline 2014 & 0.013 & 0.008 & 0.011 & 0.009 & 0.010 & 0.013 & 0.014 & 0.011 & 0.010 & 0.010 & 0.008 & 0.013 & 0.009 \\
\hline
\end{tabular}

than $50 \%$, in absolute value, so we do not expect further multicollinearity problems.

The positive correlation between the PF share and the ratios of population over age 65 and old dependency in Table 4 suggests higher investment in equities with aging. In order to further analyze how the pension fund investment in equities changes at elderly, we study the relation between the PF share and the 65-69, 70-74, 75-79, 80-84 and over 65 age population ratios. Table 5 shows the summary statistics of the demographic ratios in panel A, and the OLS estimation results of the population ratios on the pension fund asset share invested in equities in panel B. The standard errors are Newey and D.W. (1987) heteroskedasticity and autocorrelation robust standard errors.

Panel A shows that, among the $16.4 \%$ of the population over 65 , $4.8 \%$ are between 65 and 69 years, $4.1 \%$ between 70 and 74 years, $3.3 \%$ between 75 and $79,2.4 \%$ between 80 and 85 , and only $1.9 \%$ is older than 85 years. Panel B shows that increases in the 65-69, 75-79 and over 85 age population ratios produce a decrease in the PF share; however, an increase in the 80-85 age population ratio produces an increase in the pension fund assets invested in equities. Finally, the 70-74 age population cohort does not influence the PF equity share. These results show different risk profiles at elderly. Blake, Wright, and Zhang (2014) find that equity holdings on pension funds depend on the member's risk aversion, being significant equity holdings on the retirement date. Gerber and Weber (2007) point out that a substantial pension fund reserve could moderate the conservative investment with aging, which might explain our positive relation for the 80-85 age population. Nonetheless, in general, pensioners are conservative investors, consistent with prior works (Bikker, Broeders, Hollanders, \& Ponds, 2009).

\section{Methodology}

In this section, we present the empirical models developed to study the pension fund influence on market development and efficiency.

\subsection{Pension fund impact on market development}

The first model investigates the relationship between the pension fund investment in equities and stock market development:

$$
\begin{aligned}
\text { Mc_gdp } p_{i t}= & \alpha_{i}+\beta_{1} \text { PF }_{\text {share }}+\beta_{2} R m_{i t}+\beta_{3} \sigma_{m i t} \\
& +\beta_{4} G D I \_g d p_{i t}+\beta_{5} \text { Publicdebt_gdp } p_{i t}+\varepsilon_{i t}
\end{aligned}
$$

Where: $M c \_g d p_{i t}$ is the market capitalization over GDP (proxy for market development) of country $i$ in year $t, \alpha_{\mathrm{i}}$ is the country-specific intercept, $P F$ share is the share of pension fund assets invested in equities in country $i$ and year $t$. We expect $\beta_{1}$ to be positive; that is, more pension fund assets invested in stocks promotes stock market development. The set of control variables are the annual market return $\left(R_{m i t}\right)$, the annual volatility $\left(\sigma_{m i t}\right)$, the annual Gross Domestic Income over GDP (GDI_gdp ${ }_{i t}$ ) of country $i$ in year $t$ and the annual public debt over GDP (Publicdebt gdp ${ }_{i t}$ ) of country $i$ in year $t$. $\beta_{2}$ and $\beta_{4}$ coefficients are expected to be positive, showing a positive relationship between market development, market return, and GDI (performance and growth have direct influence on market development; Meng \& Pfau, 2010). However, $\beta_{3}$ and $\beta_{5}$ are expected to be negative because of the negative effect of volatility on stock markets (Meng \& Pfau, 2010, Thomas et al. 2014) and the burden of higher public debt to the market growth (Thomas et al. 2014).

In order to study whether the relationship between pension fund investment and stock market development is influenced by aging, we estimate three additional models. Models (2), (3) and (4) analyze the relationship between pension funds and stock markets, considering different levels of population between 15 and 64 years, the population over age 65 , and older dependents, respectively. The first model is represented as follows:

$$
\begin{aligned}
\text { Mc_gdp } p_{i t}= & \alpha_{i}+\beta_{1} \text { PFshare }_{i t} \\
* & \text { Popu } 1564_{i t}+\beta_{2} R m_{i t}+\beta_{3} \sigma_{m i t} \\
& +\beta_{4} G D I \_g d p_{i t}+\beta_{5} \text { Publicdebt_gdp } p_{i t}+\varepsilon_{i t}
\end{aligned}
$$

Where: Popu1564 is the ratio of population between 14 and 65 years, with regard to the total population of country $i$ in year $t$. The interaction term PFshare $_{\text {it }}$ * Popu1564 ${ }_{\text {it }}$ examines the impact of pension fund investment in equities on the stock market, with different levels of working-age population. This model attempts to ascertain whether a higher level of working-age population produces larger pension fund impact on stock markets. 
Table 4

Correlation matrix.

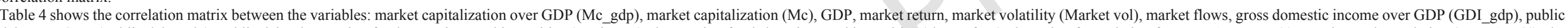

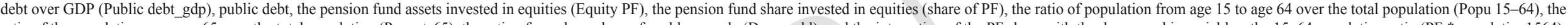

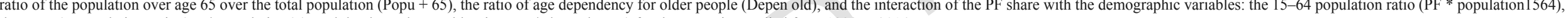
the over-65-population ratio ( $\mathrm{PF} *$ population65), and the dependency old ratio - $\mathrm{PF} *$ dependency-) for the countries studied from 1999 to 2014.

\begin{tabular}{|c|c|c|c|c|c|c|c|c|c|c|c|c|c|c|c|c|c|}
\hline & Mc_gdp & Mc & GDP & $\begin{array}{l}\text { Market } \\
\text { return }\end{array}$ & $\begin{array}{l}\text { Market } \\
\text { volatility }\end{array}$ & $\begin{array}{l}\text { Market } \\
\text { flows }\end{array}$ & GDI_gdp & $\begin{array}{l}\text { Public } \\
\text { debt_gdp }\end{array}$ & $\begin{array}{l}\text { Public } \\
\text { debt }\end{array}$ & $\begin{array}{l}\text { Equity } \\
\text { PF }\end{array}$ & $\begin{array}{l}\text { Share of } \\
\text { PF }\end{array}$ & $\begin{array}{l}\text { Popu } \\
15-64\end{array}$ & $\begin{array}{l}\text { Popu } \\
+65\end{array}$ & $\begin{array}{l}\text { Depen } \\
\text { old }\end{array}$ & $\begin{array}{l}\mathrm{PF} * \text { pop } \\
15-64\end{array}$ & $\begin{array}{l}\mathrm{PF} * \text { pop } \\
+65\end{array}$ & $P F *$ dep \\
\hline Mc_gdp & 1 & & & & & & & & & & & & & & & & \\
\hline $\mathrm{Mc}$ & 0.437 & 1 & & & & & & & & & & & & & & & \\
\hline GDP & 0.002 & 0.764 & 1 & & & & & & & & & & & & & & \\
\hline Market return & 0.168 & 0.034 & -0.043 & 1 & & & & . & & & & & & & & & \\
\hline Market vol & -0.292 & -0.229 & -0.079 & -0.488 & 1 & 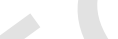 & & & & & & & & & & & \\
\hline Market flows & 0.165 & 0.032 & -0.051 & 0.960 & -0.533 & & & & & & & & & & & & \\
\hline GDI_gdp & 0.246 & 0.424 & 0.337 & -0.026 & 0.023 & -0.091 & 1 & & & & & & & & & & \\
\hline Public debt_gdp & -0.298 & -0.225 & -0.259 & -0.085 & -0.124 & -0.027 & 0.016 & 1 & & & & & & & & & \\
\hline Public debt ${ }^{-}$ & 0.034 & 0.748 & 0.940 & -0.071 & -0.105 & -0.080 & 0.395 & -0.031 & 1 & & & & & & & & \\
\hline Equity PF & 0.299 & 0.669 & 0.346 & 0.016 & -0.160 & 0.003 & 0.502 & -0.169 & 0.3429 & 1 & & & & & & & \\
\hline Share of PF & 0.238 & -0.105 & -0.365 & 0.066 & -0.175 & 0.064 & -0.008 & -0.217 & -0.401 & 0.391 & 1 & & & & & & \\
\hline Popu15-64 & 0.109 & -0.364 & -0.446 & 0.081 & 0.138 & 0.110 & -0.460 & -0.194 & -0.489 & -0.367 & 0.232 & 1 & & & & & \\
\hline Popu + 65 & -0.107 & -0.012 & 0.008 & -0.102 & -0.051 & -0.116 & 0.384 & 0.364 & 0.024 & 0.140 & 0.081 & -0.470 & 1 & & & & \\
\hline Depen. old & -0.117 & 0.037 & 0.066 & -0.105 & -0.067 & -0.121 & 0.427 & 0.368 & 0.084 & 0.177 & 0.046 & -0.569 & 0.993 & 1 & & & \\
\hline PF* pop15-64 & 0.237 & -0.117 & -0.372 & 0.068 & -0.173 & 0.067 & -0.035 & -0.220 & -0.411 & 0.370 & 0.999 & 0.261 & 0.069 & 0.032 & 1 & & \\
\hline $\mathrm{PF} *$ pop +65 & 0.200 & -0.098 & -0.345 & 0.042 & -0.168 & 0.036 & 0.059 & -0.154 & -0.371 & 0.399 & 0.979 & 0.143 & 0.259 & 0.223 & 0.9763 & 1 & \\
\hline $\mathrm{PF} * \mathrm{dep}$ & 0.200 & -0.086 & -0.337 & 0.040 & -0.170 & 0.033 & 0.083 & -0.151 & -0.360 & 0.417 & 0.977 & 0.115 & 0.269 & 0.236 & 0.9721 & 0.9994 & 1 \\
\hline
\end{tabular}


Table 5

Relation between the pension fund investment in equities and the population over 65 years.

Table 5 is divided into two panels. Panel A shows several statistics (mean, standard deviation, minimum and maximum) of the ratios of population from age 65 to 69 , from age 70 to 74 , from 75 to 79 , from 80 to 85 and over age 85 . Panel B shows the OLS estimation result of the different over-65-age-population ratios on the pension fund share variable (percentage of pension fund assets invested in equities over the total pension fund assets).

\begin{tabular}{|c|c|c|c|c|c|c|}
\hline \multicolumn{7}{|c|}{ Panel A: Summary statistics of the over- 65 population ratios } \\
\hline \multicolumn{2}{|l|}{ Variable } & Mean & Std. Dev. & Min & \multicolumn{2}{|l|}{ Max } \\
\hline Population : & ge $65-69$ & 0.048 & 0.007 & 0.033 & 0.066 & \\
\hline Population : & $70-74$ & 0.041 & 0.006 & 0.027 & 0.062 & \\
\hline Population s & $75-79$ & 0.033 & 0.005 & 0.021 & 0.048 & \\
\hline Population & $80-85$ & 0.024 & 0.004 & 0.015 & 0.033 & \\
\hline Population & ver age 85 & 0.019 & 0.004 & 0.01 & 0.031 & \\
\hline \multicolumn{7}{|c|}{ Panel B: Relation between pension fund share in equities and the over- 65 population $\mathrm{r}$ : } \\
\hline Pop 65-69 & Pop70-74 & Pop 75-79 & Pop $80-85$ & Pop more 85 & Constant & $\mathrm{R}$ \\
\hline $\begin{array}{l}-7.474 * * * \\
(1.743)\end{array}$ & $\begin{array}{l}1.999 \\
(2.443)\end{array}$ & $\begin{array}{l}-18.377 * * * \\
(3.41)\end{array}$ & $\begin{array}{l}11.185^{* * *} \\
(3.572)\end{array}$ & $\begin{array}{l}-13.421 * * * \\
(3.052)\end{array}$ & $\begin{array}{l}1.106^{* * *} \\
(0.066)\end{array}$ & \\
\hline
\end{tabular}

Model (3) includes the aging population effect with regard to the total population.

$$
\begin{aligned}
M c \_g d p_{i t}= & \alpha_{i}+\beta_{1} \text { PFshare }_{i t} \\
* & \text { Popu } 65_{i t}+\beta_{2} R m_{i t}+\beta_{3} \sigma_{m i t}+\beta_{4} G D I \_g d p_{i t} \\
& +\beta_{5} \text { Publicdebt_gdp } p_{i t}+\varepsilon_{i t}
\end{aligned}
$$

Where: Popu $65_{\text {it }}$ is the ratio of population over age 65 with regard to the total population of country $i$ in year $t$. The interaction term $P F$ share $_{i t}$ * Popu65 ${ }_{i t}$ examines the impact of the pension fund assets invested in equities on the stock market at different levels of the elderly population ratio. This model attempts to determine whether more elderly people have a larger or smaller impact on the relationship between pension funds and market development. As a consequence, if we find a positive relationship between a pension fund and the stock market, and this relationship is larger when taking into account the elderly rate, then, a growth in pension fund assets invested in equities will produce greater stock market development when aging increases. This could reveal greater pension fund investment with the aging population, since the population is more concerned with future retirement with increasing aging.

The distinction between models (2) and (3) will allow us to analyze which population cohort is able to have greater influence on the pension fund-stock market relationship.

The last model includes the aging population effect, considering the working-age population, rather than the total population:

$$
\begin{aligned}
\text { Mc_gdp } \_ & \alpha_{i}+\beta_{1} \text { PF }_{i t} \text { share }_{i t} \\
* & \text { OldDepen }_{i t}+\beta_{2} \text { Rm }_{i t}+\beta_{3} \sigma_{m i t} \\
& +\beta_{4} \text { GDI_gdp } p_{i t}+\beta_{5} \text { Publicdebt_gdp } p_{i t}+\varepsilon_{i t}
\end{aligned}
$$

Where: OldDepen $_{i t}$ is the age dependency ratio for the elderly of country $i$ in year $t$. The interaction term PFshare $_{i t}$ * OldDepen $_{i t}$ examines the impact of the pension fund investment in equities on the stock market at different levels of older dependents. The reason we include this last model is to examine the aging effect when taking into account the workforce, that is, the population that is funding the public pension system. This model excludes the effect of the population under 15; therefore, we analyze whether the elderly burden supported by the workforce produces a larger effect on the relationship between pension funds and the stock market, than in model (3)

\subsection{Pension fund impact on market efficiency}

The market efficiency is examined with the variance ratio (VR) test. The VR test, developed by Lo and MacKinlay (1988), is a standard market efficiency measure that examines whetherstock returns are serially uncorrelated, testing the random walk hypothesis (Hoque, Kim, \& Pyun, 2007). Specifically, whetherthe natural logarithm of stock prices $\left(p_{t}\right)$ follows a random walk $\left(p_{t}=\alpha+p_{t-1}+\varepsilon_{t}\right)$, the variance of the $q$ th differenced return $\left(r_{t}-r_{t-q}\right)$ is expected to be equal to $q$ times the variance of the first difference series $\left(r_{t}-r_{t-1}\right)$. The variance ratio at lag $q, V R(q)$, is:

$$
V R(q)=\sum \sigma_{c}^{2}(q) / \sum \sigma_{a}^{2}(q)
$$

Where: $\sum \sigma_{c}^{2}(q)$ is an unbiased estimator of $1 / \mathrm{q}$ of the variance of the qth differenced return series, and $\sum \sigma_{a}^{2}(q)$ is an unbiased estimator of the variance of the first-differenced return series. The null hypothesis assumes VR equals one for all lag. A VR less than one implies negative serial correlations; that is, a mean reverting process. A VR higher than one shows positive serial correlations, and VR increasing in $q$, indicates mean aversion behaviour (Jasic \& Wood, 2006).

The $V R(q)$ ratio can be rewritten as:

$$
V R(q)=1+2 \sum_{j=1}^{q-1}(1-j / q) \rho(j)
$$

Where: $\rho(j)$ is the autocorrelation or $r_{t}$ of order $j$; that is, the VR is one plus a weighted sum of autocorrelation coefficients for the returns with positive and declining weights. The null hypothesis of VR equal to 1 for all q implies that returns are serially uncorrelated and $\rho(j)=0$; therefore, VR greater than one indicates positive serial correlation and less than one implies negative serial correlation or mean reversion.

Lo and MacKinlay (1988) develop two test statistics for the VR: $M_{l}(q)$, assuming return homoskedasticity, and the heteroskedasticity robust test $M_{2}(q)$, when returns exhibit conditional heteroscedasticity; that is, when volatility is not constant over time. We apply $M_{2}(q)$ because our sample reveals heteroskedasticity in the return series (Table $3)$. The heteroskedasticity robust test $M_{2}(q)$ is:

$$
M_{2}(q)=\frac{V R(x q)-1}{\Phi^{*}(q)^{1 / 2}}
$$

$M_{2}(q)$ follows the standard normal distribution asymptotically under the null hypothesis that $V R(q)$ is one; where:

$$
\Phi^{*}(q)=\sum_{j=1}^{q-1}\left[\frac{2(q-j)}{q}\right]^{2} \delta(j)
$$


and

$$
\begin{aligned}
& \delta(j) \\
& =\left\{\sum_{t=j+1}^{T}\left(x_{t}-\hat{\mu}\right)^{2}\left(x_{t-\mathrm{j}}-\hat{\mu}\right)^{2}\right\} /\left\{\left[\sum_{t=1}^{T}\left(x_{t}-\hat{\mu}\right)^{2}\right]^{2}\right\}
\end{aligned}
$$

The value of the holding periods $q$ must be made in the estimation of $\operatorname{VR}(q)$. Following the empirical literature (Lo \& MacKinlay, 1988; Tuyon \& Ahmad, 2016; Urquhart \& Hudson, 2013), we use 2, 4, 8 and 16 holding periods.

Finally, we analyze how pension-fund investment in equities influences market efficiency with the following model:

$$
V R_{i t}=\alpha_{i}+\beta_{1} \text { PF }_{\text {share }}+\varepsilon_{i t}
$$

Where $V R_{i t}$ is the Variance Ratio of country $i$ in year $t, P F$ share ${ }_{i t}$ is the share of pension fund assets invested in equities in country $i$ and year $t$, and $\beta_{1}$ shows the relationship between pension fund investment in equities and market efficiency.

\section{Results and discussion}

First, we study the influence of pension funds on stock market development. We estimate model (1) applying different estimations in order to choose the exact specification. Following an approach similar to prior works (Thomas et al., 2014; Vo, 2015, 2016), we first estimate model (1) using OLS. Then, as additional robustness tests, we use fixed effects and random effects panel estimators. Fixed-effects panel estimations are appropriate to work on specific units, such as countries; however, if the error terms of the units and the constant are correlated, a fixed effects model is not correct, and random effects may better model the relationship (Baltagi, 2008; Thomas et al., 2014). In order to select the correct model, we perform a Hausman test. Finally, we further employ the GMM estimation of Arellano and Bond (1991) to confirm the robustness of the estimation. The panel data results of the estimations are collected in Table 6.

Estimations (1) and (2) of Table 6 show OLS estimation results. The standard errors of estimation (2) are Newey and D.W. (1987) heteroskedasticity and autocorrelation robust standard errors. The coefficient of the pension-fund share of the assets invested in equities ( $P F$ share) is significantly positive in both regressions. Therefore, larger pension fund investment in equities helps stock market development. The results also provide information about the sensitivity of market development to market volatility, GDI and public debt. Specifically, we find a significant inverse relationship with the volatility and the public debt over GDP, and a positive relationship with the GDI over GDP, as expected.

Estimations (3) and (4) show the fixed and random effects estimations. The Hausman test result (3.86) shows that the null hypothesis is not rejected and, hence, the random effect model is the appropriate specification. Although the fixed effects model is not applicable in this case, both random and fixed effects show a positive relationship between pension fund investment in equities and stock market development. We also compare the random effects and the OLS estimations with the Breusch-Pagan Lagrange multiplier (LM) for random effects to confirm the adequacy of the random effects estimation. The
LM test results reject the null hypothesis of zero variance across funds, confirming the random effects model as the proper estimation.

In order to address possible heteroskedasticity and autocorrelation in the errors, estimations (5) and (6) are estimated using fixed and random effects models with robust standard errors. The Hausman test (3.00) does not display evidence to reject the null hypothesis, so the random effects model is the correct estimation. Comparing random effects and OLS estimations, the LM test rejects the null hypothesis of zero variance across funds, so the random effects estimation provides a better fit. Furthermore, estimations (5) and (6) show again that pension fund growth influences positively on stock market development.

Estimations (7) and (8) show the fixed and random effects models with clustered standard errors by country, to address the concern of correlated errors (conditional on independent variables) within the country dimension. We do not reject the null hypothesis of the Hausman test (0.56), and the LM test null hypothesis is rejected, confirming the random effects model as the correct estimation. The results of estimations (7) and (8) show that the pension fund share invested in equities does not influence the stock market development (insignificantly positive coefficient), suggesting disparities among countries.

To confirm the robustness of the model proposed, we further use the GMM robust estimation of Arellano and Bond (1991) to control for potential model misspecification. We apply the Arellano-Bond test for serial correlation in the first-differenced errors at order 2 . The test statistic (0.604) does not allow us to reject the null hypothesis of no serial correlation; therefore, the proposed model does not suffer misspecification. The estimation (9) results confirm the positive influence of equity pension fund growth on stock market development (estimations 1-6); result in line with prior works (Catalan et al., 2000; Meng \& Pfau, 2010; Walker \& Lefort, 2002). Nonetheless, the heteroskedasticity observed (estimations 7 and 8) suggests disparities among countries, so we also carry out an analysis by country in Section 4.2

\subsection{The impact of demographic variables on the relationship between pension funds and stock market development}

In this section, we study whether the relationship between pension funds and stock market development is influenced by population aging. Table 7 collects the results of models (2), (3), and (4), in which different demographic variables are used to capture this influence. The influence of the population between ages 15 and 64 is collected in estimation (1), the influence of the population over age 65 is collected in estimation (2), and the influence of older dependents is collected in estimation (3). All models are estimated with random effects, and standard errors are robust.

Table 7 shows that the coefficients of the PFshare * Demographic variables are positive and significant. As the demographic ratios are positive, ${ }^{7}$ we find that the pension fund impact on stock market development remains positive and significant when the population increases. Specifically, pension fund growth impacts positively on stock market development when the population between ages 15 and 64 increases (estimation 1). This result shows that a larger working age population results in higher equity pension fund savings, which promotes stock market capitalization. Estimation (2) shows a positive relationship between pension fund investment and stock market development when the elderly population increases, revealing that the population (both young and old) is more concerned about

\footnotetext{
${ }^{7}$ These results may be also driven by some small ratios of pension fund assets invested in equities with regard to market capitalization and GDP.
} 
Table 6

Regression results: the influence of equity pension fund investment on stock market development.

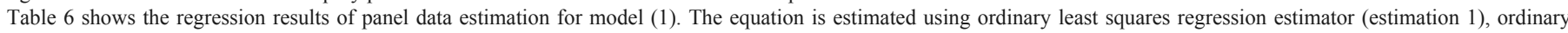

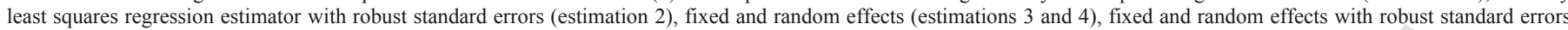

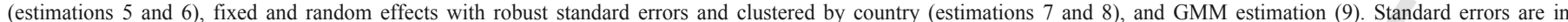
parenthesis. ${ }^{*}, * *$ and $* * *$ indicate significance at the $10 \%, 5 \%$, and $1 \%$ levels.

\begin{tabular}{|c|c|c|c|c|c|c|c|c|c|}
\hline & (1) & (2) & (3) & (4) & $(5)$ & (6) & (7) & (8) & (9) \\
\hline$M c \_g p d$ & & & & & & & & & $\begin{array}{l}0.651^{* * *} \\
(0.059)\end{array}$ \\
\hline PFshare & $\begin{array}{l}0.499 * \\
(0.27)\end{array}$ & $\begin{array}{l}0.499 * * \\
(0.204)\end{array}$ & $\begin{array}{l}0.843 * \\
(0.438)\end{array}$ & $\begin{array}{l}0.766^{* *} \\
(0.386)\end{array}$ & $\begin{array}{l}0.843 * * \\
(0.405)\end{array}$ & $\begin{array}{l}0.766 * * \\
(0.358)\end{array}$ & $\begin{array}{l}0.843 \\
(0.785)\end{array}$ & $\begin{array}{l}0.766 \\
(0.594)\end{array}$ & $\begin{array}{l}1.403 * * * \\
(0.331)\end{array}$ \\
\hline$R_{m}$ & $\begin{array}{l}-0.31 \\
(0.231)\end{array}$ & $\begin{array}{l}-0.31 \\
(0.202)\end{array}$ & $\begin{array}{l}0.146 \\
(0.125)\end{array}$ & $\begin{array}{l}0.121 \\
(0.123)\end{array}$ & $\begin{array}{l}0.146 \\
(0.093)\end{array}$ & $\begin{array}{l}0.121 \\
(0.096)\end{array}$ & $\begin{array}{l}0.146^{*} \\
(0.073)\end{array}$ & $\begin{array}{l}0.121^{* *} \\
(0.059)\end{array}$ & $\begin{array}{l}0.357 * * * \\
(0.081)\end{array}$ \\
\hline$\sigma_{m}$ & $\begin{array}{l}-36.456^{* * *} \\
(12.383)\end{array}$ & $\begin{array}{l}-36.456^{* * *} \\
(10.048)\end{array}$ & $\begin{array}{l}4.986 \\
(7.372)\end{array}$ & $\begin{array}{l}2.939 \\
(7.294)\end{array}$ & $\begin{array}{l}4.986 \\
(5.909)\end{array}$ & $\begin{array}{l}2.939 \\
(5.663)\end{array}$ & $\begin{array}{l}4.986 \\
(8.021)\end{array}$ & $\begin{array}{l}2.939 \\
(6.776)\end{array}$ & $\begin{array}{l}-0.222 \\
(6.636)\end{array}$ \\
\hline$G D I \_g d p$ & $\begin{array}{l}3.271 * * \\
(1.285)\end{array}$ & $\begin{array}{l}3.271 * * * \\
(0.964)\end{array}$ & $\begin{array}{l}3.293^{*} \\
(1.77)\end{array}$ & $\begin{array}{l}3.474 * * \\
(1.582)\end{array}$ & $\begin{array}{l}3.293 * * \\
(1.484)\end{array}$ & $\begin{array}{l}3.474 * * * \\
(1.306)\end{array}$ & $\begin{array}{l}3.293 \\
(2.783)\end{array}$ & $\begin{array}{l}3.474 \\
(2.204)\end{array}$ & $\begin{array}{l}-0.213 \\
(1.795)\end{array}$ \\
\hline Public debt_gdp & $\begin{array}{l}-0.73 * * * \\
(0.203)\end{array}$ & $\begin{array}{l}-0.73 * * * \\
(0.167)\end{array}$ & $\begin{array}{l}-0.276 \\
(0.418)\end{array}$ & $\begin{array}{l}-0.386 \\
(0.339)\end{array}$ & $\begin{array}{l}-0.276 \\
(0.308)\end{array}$ & $\begin{array}{l}-0.386 \\
(0.242)\end{array}$ & $\begin{array}{l}-0.276 \\
(0.562)\end{array}$ & $\begin{array}{l}-0.386 \\
(0.38)\end{array}$ & $\begin{array}{l}-0.169 \\
(0.355)\end{array}$ \\
\hline Constant & $\begin{array}{l}-0.547 \\
(0.892)\end{array}$ & $\begin{array}{l}-0.547 \\
(0.631)\end{array}$ & $\begin{array}{l}-1.479 \\
(1.113)\end{array}$ & $\begin{array}{l}-1.464 \\
(1.024)\end{array}$ & $\begin{array}{l}-1.479 \\
(1.002)\end{array}$ & $\begin{array}{l}-1.464^{*} \\
(0.869)\end{array}$ & $\begin{array}{l}-1.479 \\
(1.993)\end{array}$ & $\begin{array}{l}-1.464 \\
(1.646)\end{array}$ & $\begin{array}{l}0.087 \\
(1.181)\end{array}$ \\
\hline Robust standard errors & No & Yes & No & No & Yes & Yes & Yes & Yes & Yes \\
\hline Random effects & No & No & No & Yes & No & Yes & No & Yes & No \\
\hline Fixed effects & No & No & Yes & No & Yes & No & Yes & No & No \\
\hline SE cluster by country & No & No & No & No & No & No & Yes & Yes & No \\
\hline GMM estimation & No & No & No & No & No & No & No & No & Yes \\
\hline $\mathrm{R}^{2}$ within & & & 0.104 & 0.103 & 0.104 & 0.103 & 0.104 & 0.103 & \\
\hline $\mathrm{R}^{2}$ between & & & 0.132 & 0.157 & 0.132 & 0.157 & 0.132 & 0.157 & \\
\hline $\mathrm{R}^{2} /$ adjusted/overall & 0.227 & 0.268 & 0.159 & 0.178 & 0.159 & 0.178 & 0.159 & 0.178 & \\
\hline Hausman test & & & 3.86 & & 3.00 & & 0.56 & & \\
\hline LM test & & & $79.8^{* * *}$ & & $79.8^{* * *}$ & & $79.8 * * *$ & & \\
\hline Serial correlation test ( 2 nd order) & & & & & & & & & 0.604 \\
\hline
\end{tabular}

Table 7

The pension fund influence on stock market development, taking into account demographic variables.

Table 7 shows the results of models (2), (3) and (4) estimated with random effects for all countries from 1999 to 2014; that is, the influence of pension fund investment in equities on stock market development considering demographics: the 15-64 age population ratio (estimation 1), the over 65 age population ratio (estimation 2) and the older dependents ratio (estimation 3 ). Robust standard errors are in parenthesis. *, ** and $* * *$ indicate significance at the $10 \%, 5 \%$, and $1 \%$ level, respectively.

\begin{tabular}{llll}
\hline & $(1)$ & $(2)$ & $(3)$ \\
\hline PFshare * Demographics & $1.184^{* *}$ & $4.008^{* *}$ & $2.560^{*}$ \\
& $(0.527)$ & $(1.992)$ & $(1.337)$ \\
$R_{m}$ & 0.12 & 0.117 & 0.117 \\
& $(0.095)$ & $(0.097)$ & $(0.097)$ \\
$\sigma_{m}$ & 2.931 & 3.272 & 3.221 \\
& $(5.636)$ & $(5.844)$ & $(5.864)$ \\
GDI_gdp & $3.492^{* * *}$ & $3.496^{* * *}$ & $3.482^{* * *}$ \\
& $(1.301)$ & $(1.314)$ & $(1.318)$ \\
Public debt_gdp & -0.387 & -0.397 & -0.396 \\
Constant & $(0.24)$ & $(0.243)$ & $(0.245)$ \\
& $-1.482^{*}$ & -1.444 & -1.426 \\
$\mathrm{R}^{2}$ within & $(0.864)$ & $(0.877)$ & $(0.881)$ \\
$\mathrm{R}^{2}$ between & 0.105 & 0.097 & 0.094 \\
$\mathrm{R}^{2}$ overall & 0.155 & 0.146 & 0.147 \\
\hline
\end{tabular}

saving in equity through pension funds with increasing aging (higher coefficient in estimation (2) than estimation (1)), so the elderly hold some investment in stocks after retirement, contrary to some arguments (Bergantino, 1998; Goyal, 2004; Poterba, 1998). The latter behaviour lies in the fact that increasingly fewer retirees withdraw savings in single lump sums, keeping part of the savings in the pension fund after retirement because of longer life-expectancy. The estimation (3) results confirm that pension fund growth contributes to stock market development when the aging increases. The PFshare * OldDepend coefficient of this estimation is lower than the PFshare * Popu65 coefficient of estimation (2), showing that more el- derly people as a proportion of the working-age population reduce the positive impact of pension funds on the stock market, since the public pension burden supported by the labour force is greater.

These results may also reveal changes in consumers' preferences and different risk averseness among the elderly. In order to study this possible shift, we analyze the influence of equity pension funds on stock market at different groups of elderly population. We replicate model (3) using as interactive variables the PFshare $_{i t}$ variable times the $65-69,70-74,75-79,80-84$ and over 85 age population ratios. The results of the models with the different interactive variables are shown in estimations (1) to (5) of Table 8 , respectively. Table 8 shows positive influence of pension fund growth on stock market for the 65-69 and over 85 age cohorts, despite the fact that Table 5 displayed lower equity pension fund investment whether the population of these groups increases. This not expected result shows that these groups do not withdraw large amount of stocks with aging and still invest considerable part of their portfolios in equities. Consequently, more population in these groups positively influences on market capitalization. This behaviour might be related to a lesser risk-aversion for their lifecycle positions (Blake et al., 2014); that is, just retired or closed to the life end. The remaining groups do not influence on the market-pension fund relationship.

\subsection{Results by pension model}

In this section, we study the relationship between pension funds and stock market development by pension model and country ${ }^{8}$ to detect possible differences among them. We first sort the countries

\footnotetext{
${ }^{8}$ We note that this analysis may be limited by the annual basis of the data; especially, the country analysis. Nonetheless, we have not been able to obtain higher frequency data or large period sample without significant missing observations in the different variables. Even though, we carry out the analysis to detect possible differences between models and countries.
} 
Table 8

The pension fund influence on stock market development with different cohorts of over 65 age population.

Table 8 shows the random effects results of the influence of pension fund investment in equities on stock market development considering several elderly population ratios: the 65-69 age population ratio (estimation 1), the 70-74 age population ratio (estimation 2), the 75-79 age population ratio (estimation 3 ), the 80-84 age population ratio (estimation 4 ) and the over 85 age population ratio (estimation 5 ) for all countries from 1999 to 2014 . Robust standard errors are in parenthesis. *, ** and *** indicate significance at the $10 \%, 5 \%$, and $1 \%$ level, respectively.

\begin{tabular}{llllll}
\hline & $(1)$ & $(2)$ & $(3)$ & $(4)$ & $(5)$ \\
\hline PFshare *Demographics & $17.409^{* *}$ & 14.923 & 15.736 & 19.989 & $44.364 *$ \\
& $(7.145)$ & $(10.069)$ & $(10.539)$ & $(12.842)$ & $(19.877$ \\
$R_{m}$ & 0.117 & 0.121 & 0.12 & 0.108 & 0.108 \\
& $(0.095)$ & $(0.098)$ & $(0.098)$ & $(0.097)$ & $(0.095)$ \\
$\sigma_{m}$ & 3.121 & 2.412 & 2.512 & 2.801 & 2.763 \\
& $(5.646)$ & $(5.783)$ & $(5.805)$ & $(5.875)$ & $(5.621)$ \\
GDI_gdp & $3.409^{* * *}$ & $3.479 * * *$ & $3.511^{* * *}$ & $3.518^{* * *}$ & $3.237 * *$ \\
& $(1.303)$ & $(1.319)$ & $(1.316)$ & $(1.299)$ & $(1.304)$ \\
Public debt_gdp & $-0.421^{*}$ & -0.41 & -0.397 & -0.369 & -0.371 \\
& $(0.246)$ & $(0.251)$ & $(0.253)$ & $(0.252)$ & $(0.25)$ \\
Constant & -1.399 & -1.391 & -1.402 & -1.409 & -1.307 \\
& $(0.857)$ & $(0.875)$ & $(0.88)$ & $(0.861)$ & $(0.854)$ \\
$\mathrm{R}^{2}$ within & 0.080 & 0.111 & 0.079 & 0.078 & 0.108 \\
$\mathrm{R}^{2}$ between & 0.157 & 0.155 & 0.146 & 0.141 & 0.143 \\
$\mathrm{R}^{2}$ overall & 0.169 & 0.174 & 0.157 & 0.151 & 0.160 \\
\hline
\end{tabular}

studied by pension model (Anglo-Saxon, Continental, Mediterranean, and Nordic).

Table 9 shows the pool panel results of the PFshare coefficient of model (1) and the PFshare * demographic coefficients of models (2), (3) and (4) by pension model. The models are estimated with random effects. The Newey and D.W. (1987) heteroskedasticity and autocorrelation robust standard errors are displayed.

Table 9 does not display significant results for the Anglo-Saxon model. In the continental pension model, higher equity pension fund assets have larger positive impact on the stock market development whether the old-dependent ratio increases (estimation 4). The Mediterranean pension-model countries contribute to market development whether the pension fund investment in equities increases (model 1), and larger population means a more positive impact of equity pension fund growth on stock market development (models 2-4). The positive influence of population may lie on increasing doubts about the future viability of Mediterranean public pension systems. Consequently, the population is more concerned about saving, even at retirement. Additionally, governments have promoted the investment in pension funds through tax benefits, boosting this industry. On the other hand, the Nordic model results show that increasing elderly people negatively impacts stock market through equity pension funds (estimations 3 and 4). This result is consistent with the more conservative risk profile of the older people in prior works (Bergantino, 1998; Goyal, 2004; Poterba, 1998). This result, opposite to the Continental and Mediterranean model results, is explained by the mixed public pension systems (pay-as-you-go and capitalization) of the Nordic countries. The capitalization system is based on saving part of the workers' salary on public pension funds with specific investment rules; therefore, the investment in voluntary and private pension funds is lower, especially in equity pension funds.

The discrepancies of the elderly effect among models lead us to further analyze the influence of different elderly groups. We repeat the analysis of Table 8 by pension model. The results (not reported) ${ }^{9}$ show that increases on the 65-69 and the over- 85 age population in

\footnotetext{
${ }^{9}$ These results are not reported for space issues, but they are available upon request.
}

\section{Table 9}

Pension fund influence on stock market development, by pension model.

Table 9 shows the PF coefficients of models (1), (2), (3) and (4) by pension model, estimated on a pool basis with random effects, from 1999 to 2014. The Anglo-Saxon model includes Ireland and the UK, the Continental model is formed by Austria, Belgium, and Germany, the Mediterranean model is formed by Italy, Portugal, and Spain, and the Nordic model is formed by Denmark, Finland, the Netherlands, Norway, and Sweden. Estimation (1) results show the influence of pension fund investment in equities on stock market development, and estimations (2)-(4) show this influence taking into account demographic variables: ratio of population between ages 15 and 64 (estimation 2), ratio of population over age 65 (estimation 3 ) and ratio of older dependents (estimation 4). Robust standard errors are in parenthesis. *, ** and $* * *$ indicate significance at the $10 \%, 5 \%$, and $1 \%$ level, respectively.

\begin{tabular}{lllll}
\hline & $(1)$ & $(2)$ & $(3)$ & $(4)$ \\
\hline Anglo-Saxon & -0.745 & -1.169 & -4.114 & -2.593 \\
& $(0.808)$ & $(1.229)$ & $(4.737)$ & $(3.102)$ \\
Continental & 0.431 & 0.616 & 2.907 & $2.033^{*}$ \\
& $(0.285)$ & $(0 . .423)$ & $(1.642)$ & $(1.103)$ \\
Mediterranean & $3.364^{* * *}$ & $5.069 * * *$ & $11.698^{* * *}$ & $7.403^{* *}$ \\
& $(0.933)$ & $(1.419)$ & $(4.468)$ & $(3.061)$ \\
Nordic & -0.869 & -1.343 & $-8.231^{*}$ & $-5.231^{*}$ \\
& $(0.939)$ & $(1.432)$ & $(4.249)$ & $(2.785)$ \\
\hline
\end{tabular}

Continental countries and increases on the 70 to the over- 85 age population in Mediterranean countries positively influence the market through pension funds. Furthermore, increases on the 70 to the over-85 age population negatively influence on Nordic markets. This evidences that the elderly do not equally affect stock markets and depends on the age cohort and the pension model. Specifically, pension fund investors of Mediterranean countries present the highest risk profile at retirement, attempting to compensate public pension cutbacks, while the Nordic pension fund investors are the most conservative.

With regard to the non-significant results of estimation (1) in Table 9 (except in the Mediterranean model), these may be explained in two ways. First, countries included in a pension model are very distinct, or second, models are converging because many countries have applied similar reforms in the public pension systems in recent years (retirement age delay, longer working life, and introduction of sustainability factors, among others-OECD, 2012). To further analyze this issue, we perform a country-level analysis.

The country analysis results are collected in Table 10. Anglo-Saxon countries (Ireland and UK) do not report significant results, consistent with Table 9. Among continental countries, a pension fund expansion has a positive influence on the Austrian stock market (no influence in Belgium and Germany), and a larger population supposes a more positive impact of pension funds on the stock market. Concerning Mediterranean countries, the Spanish and Italian pension fund industries have no influence on stock market development, and Portuguese pension fund advances help stock market development. The lack of results in Italy may be explained by the specific pension fund regulations; the portfolio allocation of pension funds was quite restricted until 2013 (Ministerial Decree 703, 1996), and most pension fund assets were invested in fixed income assets. However, this trend changed since the 2014 reform (Ministerial Decree 166, 2014), which allows investment beyond prior limits and in other kinds of financial instruments.

The results for Nordic countries show a positive relationship between pension funds and stock market development in the Netherlands and Norway. A larger population supposes a greater impact of pension funds on stock market development in the Netherlands. The Norwegian and Danish results are independent of the demographic situation (pension funds do not affect the stock market in terms of demographics). Danish results show a negative impact of the pension fund growth on stock market development. This striking result may 
Table 10

Pension fund influence on stock market development, by country.

Table 10 shows the PF coefficient of models (1), (2), (3) and (4) estimated by country. Estimation (1) shows the influence of pension fund investment in equities on stock market development. Estimations (2)-(4) show this influence considering demographics: the ratio of population between ages 15 and 64 (estimation 2), the ratio of population over age 65 (estimation 3 ) and the ratio of older dependents (estimation 4). Robust standard errors are in parenthesis. ${ }^{*}, * *$ and $* * *$ indicate significance at the $10 \%, 5 \%$, and $1 \%$ level, respectively.

\begin{tabular}{lllll}
\hline & $(1)$ & $(2)$ & $(3)$ & $(4)$ \\
\hline Ireland & 2.307 & 3.423 & 13.388 & 9.032 \\
& $(1.038)$ & $(1.518)$ & $(6.153)$ & $(4.202)$ \\
UK & 6.022 & 9.600 & 34.593 & 21.735 \\
Austria & $(3.088)$ & $(4.893)$ & $(17.463)$ & $(11.033)$ \\
& $0.768^{* *}$ & $1.130^{* *}$ & $4.781 * *$ & $3.247 * *$ \\
Belgium & $(0.047)$ & $(0.069)$ & $(0.361)$ & $(0.247)$ \\
& -0.149 & -0.217 & -1.274 & -0.862 \\
Germany & $(3.864)$ & $(5.888)$ & $(23.319)$ & $(15.302)$ \\
& 0.967 & 1.436 & 5.985 & 4.0293 \\
Italy & $(9.207)$ & $(13.773)$ & $(61.302)$ & $(40.977)$ \\
& -5.133 & -7.746 & -31.841 & -21.101 \\
Portugal & $(3.908)$ & $(5.874)$ & $(24.591)$ & $(16.361)$ \\
& $1.518 * * *$ & $2.275^{* * *}$ & $8.022 * *$ & $5.325 * *$ \\
Spain & $(0.218)$ & $(0.315)$ & $(1.367)$ & $(0.946)$ \\
& 11.208 & 16.290 & 90.667 & 61.909 \\
Denmark & $(7.517)$ & $(10.716)$ & $(67.883)$ & $(47.114)$ \\
& $-2.489 * * *$ & -3.702 & -16.376 & -11.006 \\
Finland & $(1.774)$ & $(1.92)$ & $(9.544)$ & $(8.22)$ \\
& 2.668 & 4.018 & 13.324 & 8.8204 \\
Netherlands & $(1.835)$ & $(2.651)$ & $(11.521)$ & $(7.843)$ \\
& $5.617 * * *$ & $8.973 * * *$ & $36.198 * * *$ & $22.674 * * *$ \\
Norway & $(0.575)$ & $(0.927)$ & $(3.851)$ & $(2.393)$ \\
\multirow{2}{*}{ Sweden } & $4.751^{* * *}$ & 6.999 & 45.591 & 30.939 \\
& $(1.033)$ & $(4.63)$ & $(19.033)$ & $(14.63)$ \\
& 0.182 & 0.320 & 1.257 & 0.713 \\
& $(2.551)$ & $(3.927)$ & $(16.813)$ & $(10.914)$ \\
\hline
\end{tabular}

be due to the regulatory changes made in 2008 to discourage the massive sale of equities (Antolin, Schich, \& Yermo, 2011), which might have negative repercussions on the stock market. We find no significant results in Finland and Sweden, which can be explained by their private pension systems. Finnish private pension funds are not well developed due to the dominance of compulsory occupational pension schemes, and the major investment of private pension savings is made in life insurance companies (OECD, 2008). On the other hand, voluntary pension savings in Sweden are known as individual pension saving (IPS), which are articulated through a variety of instruments and institutions (pension insurance, banks, investment companies...); therefore, Swedish pension savings are not concentrated in pension funds, which diminishes their influence on the stock market.

Although Tables 9 and 10 reveal some heterogeneity among pension models and countries; we find generalized positive or no influence (probably because of the limited data), rather than negative impact. Consequently, our initial findings (Table 6) support the initial hypothesis that pension fund growth enhances stock market development. Furthermore, the integration of the markets analyzed in Table 6 has reduced the home bias in the analysis, holding this conclusion.

\subsection{The role of pension funds in the stock market according to the economic situation}

In this section we study how the pension fund investment in equities influences the market before and during the current economic crisis to determine whether these products have contributed to the market recession. After the generalized expansion of pension funds from 1999 to 2005-2006, the pension fund investment in equities decreased in all countries from 2007 to 2011, and continued in minimum levels, or experienced a minor recovery, from 2012 to 2014.
Given this evolution, we divide our sample into two periods: the prior-crisis period (1999-2006) and the financial crisis period (2007-2014). The results of models (1) to (4) (not reported) ${ }^{10}$ shows that the positive effect of pension funds on the market only holds before the crisis, being non-significantly positive from 2007 to 2014 . With regard to the elderly population cohorts, increases in the 65-69 and the over- 85 age population enhance market development through pension funds from 1999 to 2006, and the elderly evolution does not influence the market from 2007 to 2014 . The absence of influence during the crisis shows no pension fund repercussion in the market collapse.

\subsection{Robustness tests}

In prior sections we use the market capitalization over GDP as dependent variable to study the pension fund influence on market development. Nonetheless, pension funds may both influence the market capitalization and the GDP, so our prior results also capture the pension fund impact on GDP. In order to isolate the influence of equity pension funds on market capitalization development, we propose the alternative models (11)-(14).

$$
\begin{aligned}
& M c_{i t}=\alpha_{i}+\beta_{1} \text { equity } P F_{i t}+\beta_{2} R m_{i t}+\beta_{3} \sigma_{m i t} \\
& +\beta_{4} G D P_{i t}+\beta_{5} \text { Publicdebt }_{i t}+\varepsilon_{i t} \\
& M c_{i t}=\alpha_{i}+\beta_{1} \text { equityPF } s_{i t} \\
& \text { * Popu } 1564_{i t}+\beta_{2} R m_{i t}+\beta_{3} \sigma_{\text {mit }} \\
& +\beta_{4} G D P_{i t}+\beta_{5} \text { Publicdebt }_{i t}+\varepsilon_{i t}
\end{aligned}
$$

$$
\begin{aligned}
M c_{i t}= & \alpha_{i}+\beta_{1} \text { equityPF }_{i t} \\
* & {\text { Popu } 65_{i t}+\beta_{2} R m_{i t}+\beta_{3} \sigma_{m i t}}+\beta_{4} G D P_{i t}+\beta_{5} \text { Publicdebt }_{i t}+\varepsilon_{i t} \\
& \\
M c_{i t}= & \alpha_{i}+\beta_{1} \text { equityPF }_{i t} \\
* & \text { OldDepen }_{i t}+\beta_{2} R m_{i t}+\beta_{3} \sigma_{m i t} \\
& +\beta_{4} G D P_{i t}+\beta_{5} \text { Publicdebt }_{i t}+\varepsilon_{i t}
\end{aligned}
$$

Where: $M c_{i t}$ is the market capitalization of country $i$ in year $t$ (in million USD), $\alpha_{\mathrm{i}}$ is the country-specific intercept, equity $P F$ is the pension fund assets invested in equities in country $i$ and year $t$ (in million USD), GDP is the Gross Domestic Product of country $i$ in year $t$ (in million USD), and Publicdebt ${ }_{i t}$ is the annual public debt of country $i$ in year $t$ (in million USD). The remaining variables are defined previously.

Table 11 shows the standardized model coefficients of the pool analysis for all countries (panel A), by pension model (panel B), from 1999 to 2006 (panel C) and from 2007 to 2014 (panel D).

We first estimate the models applying the same process described in the analysis collected in Table 6, and we find that the random effects estimation is the proper fit. The results of Table 11 verify the main conclusion reached previously. We find a positive relation between the pension fund assets invested in equities and market capitalization, and larger population supports this relationship (panel A).

\footnotetext{
${ }^{10}$ These results are available upon request.
} 
Table 11

Pension fund influence on stock market capitalization.

Table 11 is divided into five panels. Panel A shows the standardized regression coefficients of models (11), (12), (13) and (14) estimated with random effects in models (1), (2), (3) and (4) for all sample, respectively. The remaining panels show the standardized regression PF coefficients of the models (11)-(14) by pension model (panel B), from 1999 to 2006 (panel C) and from 2007 to 2014 (panel D). Robust standard errors are in parenthesis. ${ }^{*}, * *$ and $* * *$ indicate significance at the $10 \%, 5 \%$, and $1 \%$ level, respectively.

\begin{tabular}{|c|c|c|c|c|}
\hline & (1) & (2) & (3) & (4) \\
\hline \multicolumn{5}{|c|}{ Panel A: All countries } \\
\hline EquityPF & $\begin{array}{l}0.32 * * * \\
(0.09)\end{array}$ & $\begin{array}{l}0.319 * * * \\
(0.09)\end{array}$ & $\begin{array}{l}0.342 * * * \\
(0.09)\end{array}$ & $\begin{array}{l}0.344 * * * \\
(0.09)\end{array}$ \\
\hline$R_{m}$ & $\begin{array}{l}-0.001 \\
(0.033)\end{array}$ & $\begin{array}{l}-0.001 \\
(0.033)\end{array}$ & $\begin{array}{l}-0.001 \\
(0.033)\end{array}$ & $\begin{array}{l}-0.001 \\
(0.033)\end{array}$ \\
\hline$\sigma_{m}$ & $\begin{array}{l}-0.104 * * * \\
(0.035)\end{array}$ & $\begin{array}{l}-0.105^{* * *} \\
(0.035)\end{array}$ & $\begin{array}{l}-0.104 * * * \\
(0.035)\end{array}$ & $\begin{array}{l}-0.103 * * * \\
(0.035)\end{array}$ \\
\hline$G D P$ & $\begin{array}{l}0.683 * * * \\
(0.133)\end{array}$ & $\begin{array}{l}0.683 * * * \\
(0.133)\end{array}$ & $\begin{array}{l}0.668 * * * \\
(0.128)\end{array}$ & $\begin{array}{l}0.668^{* * * *} \\
(0.128)\end{array}$ \\
\hline Public debt & $\begin{array}{l}-0.110 \\
(0.118)\end{array}$ & $\begin{array}{l}-0.109 \\
(0.118)\end{array}$ & $\begin{array}{l}-0.107 \\
(0.116)\end{array}$ & $\begin{array}{c}-0.108 \\
(0.116)\end{array}$ \\
\hline Constant & $\begin{array}{l}-0.05 \\
(0.06)\end{array}$ & $\begin{array}{l}-0.05 \\
(0.06)\end{array}$ & $\begin{array}{l}-0.049 \\
(0.059)\end{array}$ & $\begin{array}{l}-0.049 \\
(0.059)\end{array}$ \\
\hline \multicolumn{5}{|c|}{ Panel B: Results by pension model } \\
\hline Anglo-Saxon & $\begin{array}{l}0.743 * * * \\
(0.122)\end{array}$ & $\begin{array}{l}0.735 * * * \\
(0.122)\end{array}$ & $\begin{array}{l}0.789 * * * \\
(0.117)\end{array}$ & $\begin{array}{l}0.795 * * * \\
(0.116)\end{array}$ \\
\hline Continental & $\begin{array}{l}-1.482 \\
(1.85)\end{array}$ & $\begin{array}{l}-1.466 \\
(1.775)\end{array}$ & $\begin{array}{l}-1.533 \\
(1.798)\end{array}$ & $\begin{array}{l}-1.553 \\
(1.875)\end{array}$ \\
\hline Mediterranean & $\begin{array}{l}1.332 \\
(3.562)\end{array}$ & $\begin{array}{l}1.493 \\
(3.365)\end{array}$ & $\begin{array}{l}-1.346 \\
(5.063)\end{array}$ & $\begin{array}{l}-1.724 \\
(5.294)\end{array}$ \\
\hline Nordic & $\begin{array}{l}0.148 * * * \\
(0.047)\end{array}$ & $\begin{array}{l}0.145^{* * *} \\
(0.046)\end{array}$ & $\begin{array}{l}0.144 * * * \\
(0.049)\end{array}$ & $\begin{array}{l}0.147 * * * \\
(0.049)\end{array}$ \\
\hline \multicolumn{5}{|c|}{ Panel C: Results from 1999 to 2006} \\
\hline & $\begin{array}{l}0.313 * * \\
(0.14)\end{array}$ & $\begin{array}{l}0.313 * * \\
(0.14)\end{array}$ & $\begin{array}{l}0.325^{* *} \\
(0.144)\end{array}$ & $\begin{array}{l}0.325^{* *} \\
(0.145)\end{array}$ \\
\hline \multicolumn{5}{|c|}{ Panel D: Results from 2007 to 2014} \\
\hline & $\begin{array}{l}0.335^{* * *} \\
(0.119)\end{array}$ & $\begin{array}{l}0.328 * * * \\
(0.118)\end{array}$ & $\begin{array}{l}0.372 * * * \\
(0.118)\end{array}$ & $\begin{array}{l}0.378 * * * \\
(0.118)\end{array}$ \\
\hline
\end{tabular}

Nonetheless, Table 11 shows some differences with regard to prior outcomes. The analysis by pension model (panel B) reveals a positive influence of the pension fund growth in Anglo-Saxon and Nordic countries. This evidence is consistent with the British pension fund market expansion and the concern about saving for retirement in Nordic countries since the implementation of mixed pension systems. In addition, the differential conclusions with prior sections confirm that our initial analyses (with the Mc gdp variable) also capture the pension funds influence on the GDP.

Panel C shows a positive relation between the market capitalization and the pension funds from 1999 to 2006, consistent with the Section 4.3 results. On the other hand, this significantly positive relation does not disappear during the crisis (panel D), so the decimation of the pension fund investment in equities contributed to the market crisis. This result contrasts with the conclusions reached in Section 4.3, suggesting that decreases in the equity pension fund investment might have decelerated the GDP growth and produced a non-significant total effect on the Mc_gdp measure.

We also carry out an analysis by country (not reported), ${ }^{11}$ which exhibits higher evidence of the positive market-pension fund relationship, compared to Table 10. This relation is significant in Belgium, Denmark, Italy, Portugal, Spain and Sweden.

Overall, the market capitalization study allows us to isolate the influence of pension funds on the stock market and confirms the direct relation between the equity pension fund evolution and the stock market development. In addition, we uncover the important role of pension funds in contributing both market expansion and contraction.

\subsection{Stock market efficiency}

To study the influence of pension funds on market efficiency, we first analyze market efficiency. Table 12 collects the variance ratio (VR) for different holding levels $(2,4,8$, and 16) for all countries (panel A), by pension model (panel B), and by country (panel C). The VR is obtained from the daily natural logarithm of the MSCI-country prices.

Table 12 provides mixed evidence by holding level, pension model, and country. Panel A shows the average VR, considering all countries. The VR for $2 q^{\prime} \mathrm{s}$ is significant and slightly higher than one (1.007), not significant for $4 q$ 's, and smaller than one for 8 and 16 holding levels $(q)$. This shows that market efficiency varies over time. Specifically, market returns are positive serial-correlated in the short-term ( $2 q^{\prime}$ s), independent for $4 q^{\prime}$ s, and negative serial-correlated in the long-term ( 8 and $16 q$ 's).

The analysis by pension model (Panel B) shows that Anglo-Saxon markets are only efficient in the short-term (insignificant VR for $2 q$ 's), and there is a mean reversion processes for the other holding levels (decreasing VR with the holding level). The VR tests of the Continental model show positive serial correlation for 2 and $4 q$ 's (1.04 and $1.03 \mathrm{VR})$, but VR are not significant for 8 and $16 q$ 's, supporting market efficiency. Mediterranean markets present independent returns for 4,8 and $16 q$ 's, showing some inefficiency in the very short-term (significant 1.02 for $2 q$ 's). The VR of Nordic markets show efficiency in the very short-term $(2 q$ 's $)$ and long-term $\left(16 q^{\prime}\right.$ s $)$, while returns are negatively correlated in the medium-term $(0.96$ and 0.93 for 4 and $8 q$ 's). These unequal results show evidence of the Adaptive Market Hypothesis (AMH); that is, varying market efficiency over time and across markets. Ito and Sugiyama (2009), Lim and Brooks (2006), and Urquhart and Hudson (2013), among others, also find that market efficiency varies over time.

Panel $\mathrm{C}$ confirms shifting efficiency over time and countries. Germany, Italy and Norway possess the most efficient stock markets (non-significant VR statistics), so the null hypothesis of independence cannot be rejected. Ireland shows a VR test larger than one for $2 q$ 's, a non-significant test for $4 q$ 's, and values lower than one for 8 and $16 q$ 's, demonstrating that return dependency changes from long-term negative serial- correlated returns to short-term positive serial-correlated returns, achieving efficiency in the medium-term. VR statistics for the UK show that the market moves towards efficiency (returns are negative serial-correlated in the long-term and independent in the short-term). Our results are in line with Urquhart and Hudson (2013). Austria, Belgium, and Denmark show long-term market efficiency and no efficiency in the short-term. The most inefficient market is the Portuguese, presenting positive persistent behaviour (VR statistics greater than one). Spanish and Finnish markets are efficient (insignificant test, except for $8 q$ 's). The Dutch and Swedish markets have experienced market efficiency improvement (VR progressive increase, being non-significant for $2 q$ 's).

In order to confirm the AMH and identify possible temporal patterns, we further examine the evolution of market efficiency over time, considering economic cycles. We measure recession and boom periods using the OECD-based recession indicator of the countries studied, obtained from the Federal Reserve Economic Data ${ }^{12}$ for 1999 to 2014 on a daily basis. As a consequence, the economic cycles are different for each country. The onset of the recession is the peak of economic activity and its end is the last day of the period before the trough. The indicator is expressed as a dummy variable: a value

\footnotetext{
${ }^{12}$ Federal Reserve Economic Data: https://research.stlouisfed.org/fred2/
} 
Table 12

Market efficiency.

Table 12 shows the Variance Ratio (VR) heteroskedasticity robust test results obtained for different holding levels ( $q$ 's of 2, 4, 8, and 16) from the daily natural logarithm prices of the MSCI country indices. Panel A shows the pool results for all countries studied. Panel $\mathrm{B}$ shows the results by pension model. Panel $\mathrm{C}$ shows the results by country. $* * *$ and $* * *$ indicate significance at the $10 \%, 5 \%$, and $1 \%$ level, respectively.

\begin{tabular}{lllll}
\hline \multicolumn{1}{c}{$q=2$} & $q=4$ & $q=8$ & $q=16$ \\
\hline Panel A: All countries & & & & \\
All & $1.007^{*}$ & 0.994 & $0.972^{* *}$ & $0.959^{* *}$ \\
Panel B: Pension model analysis & & & \\
Anglo-Saxon & 1.011 & $0.95^{* *}$ & $0.857^{* * *}$ & $0.79 * * *$ \\
Continental & $1.04^{* * *}$ & $1.03^{* *}$ & 1.01 & 1 \\
Mediterranean & $1.02^{* * *}$ & 1.02 & 0.99 & 0.9 \\
Nordic & 0.98 & $0.96^{* * *}$ & $0.93^{* * *}$ & 0.9 \\
Panel C: Country analysis & & & \\
Ireland & $1.031^{* *}$ & 0.99 & $0.895^{* *}$ & $0.83^{* *}$ \\
UK & 0.977 & $0.885^{* * *}$ & $0.797^{* * *}$ & $0.74 * *$ \\
Austria & $1.056^{* * *}$ & $1.054^{*}$ & 1.057 & 1.08 \\
Belgium & $1.057^{* * *}$ & $1.064^{* *}$ & 1.044 & 1.1 \\
Germany & 1.003 & 0.974 & 0.937 & 0.93 \\
Italy & 0.991 & 0.953 & 0.926 & 0.94 \\
Portugal & $1.078^{* * *}$ & $1.103^{* * *}$ & $1.108^{* *}$ & $1.11^{*}$ \\
Spain & 1.02 & 0.974 & $0.921^{*}$ & 0.9 \\
Denmark & $1.026^{*}$ & 0.994 & 0.964 & 0.94 \\
Finland & 1.004 & 0.97 & $0.911^{*}$ & 0.91 \\
Netherlands & 0.994 & $0.935^{* *}$ & $0.884^{* *}$ & 0.89 \\
Norway & 1.002 & 0.962 & 0.926 & 0.91 \\
Sweden & 1.007 & $0.948^{*}$ & $0.865^{* * *}$ & $0.82^{* *}$ \\
\hline
\end{tabular}

of 1 shows a recession period, and a value of 0 indicates an expansion period.

Table 13 collects the VR tests for 2 holding periods, by country and economic period. Countries are ordered by pension models. Anglo-Saxon, Continental, Mediterranean, and Nordic country results are shown in panels A, B, C and D. We clarify that economic cycles differ in each country, regardless of the pension model.

Results show different VR across countries and economic cycles, confirming that market efficiency changes over time and across markets. Additionally, certain patterns are observed. We repeatedly find that returns are independent from 2004 to 2012, while inefficiency is greater at the beginning and the end of our time span: 1999-2003 (Ireland, Austria, Belgium, and Portugal) and 2012-2014 (Austria, Belgium, Italy, Portugal, the Netherlands, and Sweden). Those inefficiencies occur in expansion periods and when economic turning points are frequent (from short crisis periods to short expansion periods, and vice versa). Thus, market efficiency is affected by sudden market changes. Results for different holding levels $(4,8$, and 16) come to similar conclusions, although they are not displayed for space issues ${ }^{13}$ On the whole, the stock markets studied do not present great inefficiency problems (close to one VR), and market tends move towards efficiency, at least, in a weak-form (Doran, Peterson, \& Colby, 2010).

\subsection{Pension fund influence on stock market efficiency}

In the previous section, we show evidence of varying efficiency, a dynamic behaviour that is due to a complex combination of investors' behaviours over time (Nawrocki \& Viole, 2014). In this section, we analyze the specific impact of pension fund managers on market efficiency. Table 14 collects the model (10) results, obtained in a pool basis for all countries (Panel A), by pension model (Panel B), and by country (Panel C).

\footnotetext{
13 These results are available upon request.
}

Table 14 shows that the pension fund investment in equities barely affects stock market efficiency, although significant results are diverse. The pool analysis, including all countries (Panel A), does not detect significant influence. Panel B shows that the medium-term efficiency of Mediterranean stock markets improves when the pension fund investment in equities increases (significantly positive VR for 4 and $8 q^{\prime}$ s). In the other pension models, pension funds do not affect market efficiency.

The country analysis (Panel C) confirms an absence of pension fund influence on Anglo-Saxon markets (Ireland and the UK). Pension funds of continental countries (Belgium and Germany) do not influence market efficiency, although Austrian pension funds negatively influence medium-term market efficiency $(-1.027 \mathrm{VR}$ for $4 q$ 's). The Mediterranean pension funds influence market efficiency to a greater extent, as panel B shows. A greater pension fund investment in equities improves short-term market efficiency in Italy ( $2 q$ 's), Portugal (4 $q$ 's) and Spain ( $2 q$ 's). In Nordic countries, pension fund investment positively impacts on the medium-long term efficiency of the Danish, Finnish, Dutch, and Norwegian stock markets. Nonetheless, more pension fund assets invested in equities negatively influence the medium-term Dutch market efficiency $(-0.683 \mathrm{VR}$ for 4 $q$ 's). Swedish stock market efficiency is not affected by pension funds. These results again show great differences among Nordic countries, despite the fact that the pension model analysis did not reveal significant results (Panel B).

We also note that significant results are mainly found in countries with either low ratios of equity PF assets over total PF (Denmark and the Netherlands, Table 1) or lower PF assets over GDP (Austria, Italy and Norway, - Table 1), or both (Spain and Portugal). Furthermore, these country inefficiencies are mostly found in countries with significant pension fund influence on stock markets (Table 10). Consequently, the lower amount invested in these markets may positively impact on market development due to market inefficiencies, which occurs with an aging increase. Whether pension funds become large enough and able of moving the markets in unpleasant manners, the investment in bonds and alternative investments will become necessary to return to equilibrium. This shift will lead to an investment decrease in stock markets; although the magnitude and speed of this process will be difficult to predict. This is an interesting topic for future analyses.

Comparing Tables 12 and 14 results, we observe that the Irish, British, Belgian, German, and Swedish market (in)efficiency is not related to the level of pension fund investment. However, Austrian pension funds are partially responsible for the Austrian market inefficiency. The negative pension fund influence on the stock market $(-1.02$ for $4 q$ 's, Table 14) translates into positive serial-correlated returns for 2 and $4 q$ 's.

On the other hand, the pension funds' influence on Italian and Spanish market efficiency is very limited (significant only for 2 holding levels). The Portuguese stock market is the least efficient market (Table 12), despite the fact that Portuguese pension funds contribute to short-term market efficiency (Table 14).

The Danish, Finnish, and Norwegian pension fund industries help to improve medium-term market efficiency. The results for the Netherlands are quite revealing. While pension fund growth influences negatively market efficiency for four holding levels (Table 14), the market efficiency experiences a mean reversion process at that level (Table 12). Additionally, the market is efficient in the long-term, when the pension fund influence is positive.

These results demonstrate that market efficiency differs across markets and evolves over time. Consequently, we find that the long-term nature of pension funds does not imply greater market effi- 
Table 13

Market efficiency over time.

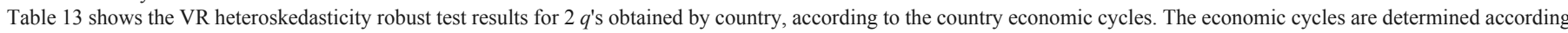

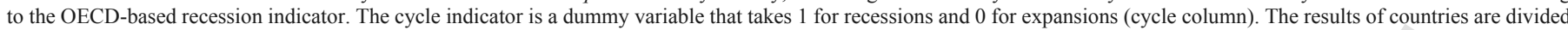

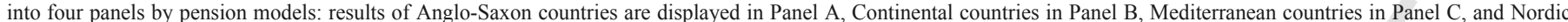
countries in Panel D.*,** and $* * *$ indicate significance at the $10 \%, 5 \%$, and $1 \%$ level, respectively.

\begin{tabular}{|c|c|c|c|c|c|}
\hline \multicolumn{3}{|l|}{ Ireland } & \multicolumn{3}{|c|}{ UK } \\
\hline Cycle & Period & VR & & Period & VR \\
\hline 0 & 1999-00 & $1.102 * *$ & 1 & 1999 & 1.028 \\
\hline 1 & $2001-04$ & $1.094 * *$ & 0 & 2000 & 1.066 \\
\hline 0 & $2005-07$ & $1.087 * *$ & 1 & 2001-02 & 0.997 \\
\hline 1 & 2008-09 & 1.023 & 0 & 2003 & 0.878 \\
\hline 0 & $2010-12$ & 1.016 & 1 & 2004 & 0.986 \\
\hline 1 & 2013 & 0.922 & 0 & 2005-07 & 0.932 \\
\hline \multirow[t]{4}{*}{0} & 2014 & 1.028 & 1 & 2008-09 & 0.971 \\
\hline & & & 0 & $2010-11$ & 1.03 \\
\hline & & & 1 & 2012 & 0.946 \\
\hline & & & 0 & 2013-14 & 0.988 \\
\hline
\end{tabular}

\begin{tabular}{|c|c|c|c|c|c|c|c|c|}
\hline \multicolumn{9}{|c|}{ Panel B: Continental countries } \\
\hline \multicolumn{3}{|c|}{ Austria } & \multicolumn{2}{|c|}{ Belgium } & & \multicolumn{3}{|c|}{ Germany } \\
\hline 0 & 1999-00 & $1.115^{* *}$ & & 1999-00 & $1.151^{*}$ & 0 & 1999-01 & 1.06 \\
\hline 1 & 2001-03 & 1 & & $2001-03$ & $1.153 * *$ & 1 & $2002-05$ & 0.995 \\
\hline 0 & 2004-08 & 1.088 & & 2004-08 & 1.082 & 0 & 2006-08 & 0.986 \\
\hline 1 & 2009 & 0.965 & & 2009 & 0.987 & 1 & 2009 & 0.935 \\
\hline 0 & 2010-11 & 1.078 & & $2010-11$ & 0.995 & 0 & $2010-11$ & 1.075 \\
\hline 1 & $2012-13$ & 1.029 & & $2012-13$ & $0.903 * *$ & 1 & $2012-13$ & 0.985 \\
\hline 0 & 2014 & $1.156^{* *}$ & & 2014 & 0.902 & 0 & 2014 & 0.879 \\
\hline \multicolumn{9}{|c|}{ Panel C: Mediterranean countries } \\
\hline \multicolumn{3}{|c|}{ Italy } & \multicolumn{2}{|c|}{ Portugal } & & \multicolumn{2}{|c|}{ Spain } & \\
\hline 1 & 1999 & 0.948 & 0 & 1999-00 & $1.121 * *$ & 0 & 1999-00 & 1.003 \\
\hline 0 & $2000-01$ & 1.022 & 1 & $2001-03$ & $1.149^{* * *}$ & 1 & 2001-04 & 1.015 \\
\hline 1 & 2002-03 & 1.007 & 0 & 2004 & 1.062 & 0 & 2005-08 & 0.977 \\
\hline 0 & 2004-08 & 0.976 & 1 & 2005 & 0.998 & 1 & 2009 & 0.97 \\
\hline 1 & 2009 & 0.998 & 0 & 2006-08 & 1.061 & 0 & $2010-11$ & 1.081 \\
\hline 0 & 2010-11 & 1.038 & 1 & 2009 & 0.905 & 1 & $2012-13$ & 1.023 \\
\hline 1 & $2012-13$ & 0.949 & 0 & 2010 & 1.074 & 0 & 2014 & 0.949 \\
\hline \multirow[t]{2}{*}{0} & 2014 & $0.856^{*}$ & 1 & $2011-13$ & $1.073^{*}$ & & & \\
\hline & & & 0 & 2014 & $1.183 * *$ & & & \\
\hline
\end{tabular}

Panel D: Nordic countries

\begin{tabular}{|c|c|c|c|c|c|c|c|c|c|c|c|c|c|}
\hline \multicolumn{3}{|c|}{ Denmark } & \multicolumn{3}{|c|}{ Finland } & \multicolumn{2}{|c|}{ Netherlands } & \multicolumn{3}{|c|}{ Norway } & \multicolumn{3}{|c|}{ Sweden } \\
\hline 0 & 1999-00 & 1.057 & 1 & 1999 & 1.035 & $1999-00$ & 0.998 & 1 & 1999 & 1.002 & 0 & 1999-00 & 0.983 \\
\hline 1 & $2001-03$ & 1.035 & 0 & 2000 & 0.982 & $2001-03$ & 1.015 & 0 & 2000 & 1.001 & 1 & $2001-03$ & $1.118^{* *}$ \\
\hline 0 & 2004-08 & 1.05 & 1 & $2001-03$ & 1.014 & 2004-08 & 0.975 & 1 & $2001-03$ & 1.07 & 0 & 2004-07 & 0.995 \\
\hline 1 & 2009 & 0.966 & 0 & 2004-07 & $1.076^{* *}$ & 2009 & 0.975 & 0 & 2004-07 & 1.037 & 1 & 2008-09 & 1.002 \\
\hline 0 & $2010-11$ & 1.018 & 1 & 2008-09 & 0.957 & $2010-11$ & 1.038 & 1 & $2008-10$ & 0.972 & 0 & $2010-11$ & 0.985 \\
\hline 1 & $2012-13$ & 0.983 & 0 & $2010-11$ & 1.043 & $2012-14$ & $0.929 *$ & 0 & $2011-12$ & 1.017 & 1 & $2012-13$ & 0.932 \\
\hline \multirow[t]{2}{*}{0} & 2014 & 0.985 & 1 & $2012-13$ & 0.996 & & & 1 & 2013 & 0.967 & 0 & 2014 & $0.885^{*}$ \\
\hline & & & 0 & 2014 & 1.017 & & & 0 & 2014 & 1.158 & & & \\
\hline
\end{tabular}

ciency; indeed, pension fund managers can improve or deteriorate market efficiency, according to the actions taken. This behaviour exhibits the need to promote market efficiency by minimizing the effect of behavioural risks in financial market governance (Cunningham, 2002; Daniel, Hirshleifer, \& Teoh, 2002; Li, 2008; Vo, 2016). In the current corporate governance scenario, regulating these risks, educating investors on behavioural risks, and introducing mechanisms to protect investors from excessive behavioural risks are all necessary to achieve better performance and fair market valuation (Klapper \& Love, 2004).

\section{Conclusions}

The gradual population aging of western countries has given rise to concerns about public pension weaknesses and the need to save for retirement; as a result, the worldwide pension fund industry has experienced significant growth over the last two decades, and pension fund managers have become influential institutional investors in stock markets. In this work, we study the role that pension funds play in European stock market development and efficiency.

Usinga panel data of 13 European countries from 1999 to 2014, we estimate the pension fund impact on stock market development by applying different estimation models (OLS, fixed-effects, random-effects, and GMM). Our results reveal that the random-effects model 
Table 14

Influence of pension fund investment in equities on market efficiency.

Table 14 shows the results of model (10), which studies the influence of pension fund investment in equities on market efficiency (VR) at different holding levels $(2,4,8$, and 16). Panels A, B, and C show the average result for all countries, results by pension model, and country, respectively. Robust standard errors are displayed in parentheses. $*, * *$ and $* * *$ indicate significance at the $10 \%, 5 \%$, and $1 \%$ level, respectively.

\begin{tabular}{|c|c|c|c|c|}
\hline & $q=2$ & $q=4$ & $q=8$ & $q=16$ \\
\hline \multicolumn{5}{|c|}{ Panel A: All countries } \\
\hline & $\begin{array}{l}0.628 \\
(-0.068)\end{array}$ & $\begin{array}{l}0.247 \\
(-0.147)\end{array}$ & $\begin{array}{l}0.644 \\
(-0.056)\end{array}$ & $\begin{array}{l}0.685 \\
(-0.048)\end{array}$ \\
\hline \multicolumn{5}{|c|}{ Panel B: Pension model analysis } \\
\hline Anglo-Saxon & $\begin{array}{l}0.708 \\
(-0.146)\end{array}$ & $\begin{array}{l}0.864 \\
(0.06)\end{array}$ & $\begin{array}{l}0.737 \\
(0.111)\end{array}$ & $\begin{array}{l}0.833 \\
(0.077)\end{array}$ \\
\hline Continental & $\begin{array}{l}0.806 \\
(-0.08)\end{array}$ & $\begin{array}{l}0.105 \\
(-0.523)\end{array}$ & $\begin{array}{l}0.181 \\
(-0.435)\end{array}$ & $\begin{array}{l}0.797 \\
(-0.093)\end{array}$ \\
\hline Mediterranean & $\begin{array}{l}0.267 \\
(0.968)\end{array}$ & $\begin{array}{l}1.605^{* * *} \\
(1.605)\end{array}$ & $\begin{array}{l}1.541 * * * \\
(1.541)\end{array}$ & $\begin{array}{l}0.819 \\
(-0.155)\end{array}$ \\
\hline Nordic & $\begin{array}{l}0.406 \\
(0.22)\end{array}$ & $\begin{array}{l}0.581 \\
(0.15)\end{array}$ & $\begin{array}{l}0.217 \\
(0.312)\end{array}$ & $\begin{array}{l}0.197 \\
(0.283)\end{array}$ \\
\hline \multicolumn{5}{|c|}{ Panel C: Country analysis } \\
\hline Ireland & $\begin{array}{l}0.817 \\
(-0.536)\end{array}$ & $\begin{array}{l}0.134 \\
(-3.088)\end{array}$ & $\begin{array}{l}0.103 \\
(-3.097)\end{array}$ & $\begin{array}{l}0.78 \\
(-0.554)\end{array}$ \\
\hline UK & $\begin{array}{l}0.197 \\
(-0.847)\end{array}$ & $\begin{array}{l}0.55 \\
(-0.283)\end{array}$ & $\begin{array}{l}0.537 \\
(0.485)\end{array}$ & $\begin{array}{l}0.243 \\
(0.817)\end{array}$ \\
\hline Austria & $\begin{array}{l}0.501 \\
(-0.286)\end{array}$ & $\begin{array}{l}-1.027 * * \\
(-1.027)\end{array}$ & $\begin{array}{l}0.164 \\
(-0.629)\end{array}$ & $\begin{array}{l}0.54 \\
(0.297)\end{array}$ \\
\hline Belgium & $\begin{array}{l}0.977 \\
(-0.05)\end{array}$ & $\begin{array}{l}0.18 \\
(2.421)\end{array}$ & $\begin{array}{l}0.653 \\
(-0.574)\end{array}$ & $\begin{array}{l}0.608 \\
(-1.347)\end{array}$ \\
\hline Germany & $\begin{array}{l}0.688 \\
(-4.195)\end{array}$ & $\begin{array}{l}0.575 \\
(-6.884)\end{array}$ & $\begin{array}{l}0.195 \\
(-10.89)\end{array}$ & $\begin{array}{l}0.937 \\
(-0.733)\end{array}$ \\
\hline Italy & $\begin{array}{l}6.482 * \\
(6.482)\end{array}$ & $\begin{array}{l}0.522 \\
(-2.001)\end{array}$ & $\begin{array}{l}0.282 \\
(-3.199)\end{array}$ & $\begin{array}{l}0.685 \\
(-1.654)\end{array}$ \\
\hline Portugal & $\begin{array}{l}0.964 \\
(-0.068)\end{array}$ & $\begin{array}{l}1.969 * * \\
(1.969)\end{array}$ & $\begin{array}{l}0.145 \\
(1.172)\end{array}$ & $\begin{array}{l}0.628 \\
(-0.485)\end{array}$ \\
\hline Spain & $\begin{array}{l}2.137 * \\
(2.137)\end{array}$ & $\begin{array}{l}0.963 \\
(-0.093)\end{array}$ & $\begin{array}{l}0.306 \\
(1.506)\end{array}$ & $\begin{array}{l}0.496 \\
(-1.085)\end{array}$ \\
\hline Denmark & $\begin{array}{l}0.263 \\
(0.962)\end{array}$ & $\begin{array}{l}1.695^{*} \\
(1.695)\end{array}$ & $\begin{array}{l}0.207 \\
(1.156)\end{array}$ & $\begin{array}{l}0.535 \\
(0.577)\end{array}$ \\
\hline Finland & $\begin{array}{l}0.199 \\
(0.835)\end{array}$ & $\begin{array}{l}0.337 \\
(1.003)\end{array}$ & $\begin{array}{l}2.119 * * \\
(2.119)\end{array}$ & $\begin{array}{l}2.118^{* *} \\
(2.118)\end{array}$ \\
\hline Netherlands & $\begin{array}{l}0.156 \\
(0.517)\end{array}$ & $\begin{array}{l}-0.683 * * \\
(-0.683)\end{array}$ & $\begin{array}{l}0.881 \\
(-0.047)\end{array}$ & $\begin{array}{l}0.502 * \\
(0.502)\end{array}$ \\
\hline Norway & $\begin{array}{l}0.703 \\
(0.443)\end{array}$ & $\begin{array}{l}2.072 * * * \\
(2.072)\end{array}$ & $\begin{array}{l}2.022 * * * \\
(2.022)\end{array}$ & $\begin{array}{l}0.119 \\
(1.447)\end{array}$ \\
\hline Sweden & $\begin{array}{l}0.548 \\
(0.371)\end{array}$ & $\begin{array}{l}0.745 \\
(0.273)\end{array}$ & $\begin{array}{l}0.754 \\
(0.212)\end{array}$ & $\begin{array}{l}0.78 \\
(0.158)\end{array}$ \\
\hline
\end{tabular}

estimated with robust standard errors is the correct estimation. Unlike prior works, we only consider the pension fund assets invested in equities, not the total pension fund assets, and still find that higher pension fund investment in equities positively influences stock market development. In general, we find positive pension fund impact on stock market development. Nonetheless, our results are heterogeneous among countries, independently of the pension model, which reveals differences between the countries studied, and between the countries included in a pension model. Even though, the country analysis reveals positive or no influence, rather than negative pension fund impact on stock market development.

Considering the aging population, we observe that an equity pension fund growth influences more positively on stock market development when the population increases, whether or not the population is, relatively, young or old. This result reveals a concern about saving for retirement as aging increases; nevertheless, we find different risk profile among the elderly, and some elderly groups tend to decrease their pension fund investment in equities.

On the other hand, the efficiency analysis shows that market efficiency varies over time and across markets. Moreover, the influence of pension funds on market efficiency is not clear. Pension fund managers vary their management strategies with market circumstances, so the long-term nature of pension funds does not imply greater efficiency. We find that pension fund managers' actions can improve, deteriorate, or not affect market efficiency. Understanding the role of these institutional investors on stock markets may suppose the successful implementation of market policies (Vo, 2016) and pension reforms that will benefit stock market expansion, alleviate aging problems, and ensure public pension viability.

\section{Acknowledgment}

I want to thank for the funding support to Ibercaja and University of Zaragoza [grant number JIUZ-2015-SOC-01].

\section{References}

Abreu, D., Brunnermeier, M.K., 2002. Synchronization risk and delayed arbitrage. Journal of Financial Economics 66, 341-360.

Abreu, D., Brunnermeier, M.K., 2003. Bubbles and crashes. Econometrica $71,173-204$

Antolin, P., Schich, S., Yermo, J., 2011. Economic impact of protracted low interest rates on pension funds and insurance companies. OECD Journal: Financial Market Trends 1, 1-20.

Arellano, M., Bond, S., 1991. Some tests of specification for panel data: Monte Carlo evidence and an application to employment equations. The Review of Economic Studies 58 (2), 277-297.

Badrinath, S.G., Wahal, S., 2002. Momentum trading by institutions. Journal of Finance 57 (6), 2449-2478.

Baltagi, B., 2008. Econometric analysis of panel data. John Wiley \& Sons Ltd, Chich-ester.

Barber, B.M., Lee, Y.-T., Liu, Y.-J., Odean, T., 2009. Just how much do individual investors lose by trading?. Review of Financial Studies 22, 609-632.

Bergantino, S., 1998. Lifecycle investment behavior, demographics, and asset prices (Doctoral Dissertation). Massachusetts Institute of Technology, Department of Economics.

Bertola, G., Boeri, T., Nicoletti, G. (Eds.), 2001. Welfare and employment in a united Europe. MIT Press, Cambridge Mass.

Bikker, J., Broeders, D., Hollanders, D., Ponds, E., 2009. Pension funds' asset allocation and participant age: A test of the life-cycle model. DNB working paper $n^{\circ}$ 223.

Blake, D., Wright, D., Zhang, Y., 2014. Age-dependent investing: Optimal funding and investment strategies in defined contribution pension plans when members are rational lifecycle financial planner. Journal of Economic Dynamics and Control 38, 105-124.

Boehmer, E., Kelley, E.K., 2009. Institutional investors and the informational efficiency of prices. Review of Financial Studies 22, 3563-3594.

Boeri, T., 2002. let social policy models compete and Europe will win. Paper presented at a conference hosted by the Kennedy School of Government, Harvard University, 11-12 April.

Brock, W., Lakonishok, J., LeBaron, B., 1992. Simple technical trading rules and the stochastic properties of stock returns. Journal of Finance 47 (5), 1731-1764.

Brooks, R., 2002. Asset market effects of the baby-boom and social security reform. American Economic Review 92, 402-406.

Brown, N., Wei, K., Wermers, R., 2007. Analyst recommendations, mutual fund herding and overreaction in stock prices. working paper. University of Maryland.

Brunnermeier, M.K., Nagel, S., 2004. Hedge funds and technology bubble. Journal of Finance 59, 2013-2040.

Casalegno, L., 2006. On some aspects of the European social model(s). Centro Studi Sul Federalismo. Available at: http://www.federalist-debate.org/index.php/ component/k2/item/385-on-some-aspects-of-the-european-social-models.

Catalan, M., Impavido, G., Musalem, A.R., 2000. Contractual savings or stock market development-which leads? World Bank publications 2421.

Clark, G.L., 2000. Pension fund capitalism. Oxford University Press, Oxford.

Cunningham, L.A., 2002. Behavioral finance and investor governance. Washington and Lee Law Review 59 (3), 767-837.

Daniel, K., Hirshleifer, D., Teoh, S.H., 2002. Investor psychology in capital markets: Evidence and policy implications. Journal of Monetary Economics 49, 139-209.

Davis, E.P., 1995. Pension funds-retirement income security and capital markets-an international. Perspective-Clarendon Press, Oxford.

Davis, E.P., 2004. Financial development, institutional investors and economic performance. In: Goodhart, C.A.E. (Ed.), Financial development and economic growth: Explaining the links. Palgrave-Macmillan, London.

Davis, E.P., Hu, Y.-W., 2004. Is there a link between pension-fund assets and economic growth? A cross-country study. Brunel University and NIESR, mimeo.

Davis, E.P., Li, C., 2003. Demographics and financial asset prices in the major industrial economics, working paper 03-07. Brunel University, London. 
Demirguc-Kunt, A., Levine, R., 1996. Stock market development and financial intermediaries: Stylized facts. World Bank Economic Review 10, 291-321.

Disney, R., Johnson, P., 2001. Pension systems and retirement incomes across OECD countries. Edward Elgar Editor, UK.

Doran, J.S., Peterson, D.R., Colby, W., 2010. Confidence, opinions of market efficiency, and investment behavior of finance professors. Journal of Financial Market $13,174-195$.

Dow, J., Gorton, G., 1997. Noise trading, delegated portfolio management, and economic welfare. Journal of Political Economy 105, 1024-1050.

European Commission, 2001. Economic policy committee report. Budgetary challenges posed by aging populations. European Commission.

Fama, E.F., 1970. Efficient capital markets: A review of the theory and empirical work. Journal of Finance 25 (2), 383-417.

Fama, E.F., French, K.R., 1988. Permanent and temporary components of stock prices Journal of Political Economy 96 (2), 246-273.

Ferrera, M., 1998. The four social Europes: Between universalism and selectivity. In: Rhodes, Meny (Eds.), The future of European welfare: A new social contract? Macmillan, London, pp. 81-96.

Ferrera, M., 2013. From protection to investment? New frontiers for the European social model(s). paper presented at 6th EU-India Joint Seminar on Employment and Social Policy. Available at http://ec.europa.eu/social $/$ main.jsp?catId=88\& langId=en\&eventsId=853\&moreDocuments=yes\&tableName=events\&typeId $=92$.

Gerber, D., Weber, R., 2007. Aging, asset allocation, and costs: Evidence for the pension fund industry in Switzerland IMF working paper WP/07/29.

Goldman, E., Slezak, S.L., 2003. Delegated portfolio management and rational prolonged mispricing. Journal of Finance 58, 283-311.

Goyal, A., 2004. Demographics, stock market flows, and stock returns. Journal of Financial and Quantitative Analysis 39 (March), 115-142.

Griffin, J.M., Harris, J.H., Topaloglu, S., 2003. The dynamics of institutional and individual trading. Journal of Finance 58, 2285-2320.

Hong, H., Scheinkman, J., Xiong, W., 2008. Advisors and asset prices: A model of the origins of bubbles. Journal of Financial Economics 89, 268-287.

Hoque, H.A.A.B., Kim, J.H., Pyun, C.S., 2007. A comparison of variance ratio tests of random walk: A case of Asian emerging stock markets. International Review of Economics and Finance 16, 488-502.

$\mathrm{Hu}, \mathrm{Y} ., 2012$. Growth of Asian pension assets: Implications for financial and capital markets. ADBI working paper series, 360.

Impavido, G., Musalem, A.R., Tressel, T., 2003. The impact of contractual savings institutions on securities markets. In: World Bank policy research working paper 2948. The World Bank, Washington, DC.

Ito, M., Sugiyama, S., 2009. Measuring the degree of time varying market inefficiency. Economics Letters 103 (1), 62-64.

Jasic, T., Wood, D., 2006. Testing for efficiency and non-linearity in market and natural time series. Journal of Applied Statistics 33 (2), 113-138.

Jegadeesh, N., Titman, S., 1993. Returns to buying winners and selling losers: Implications for stock market efficiency. Journal of Finance 48 (1), 65-91.

Klapper, L.F., Love, I., 2004. Corporate governance, investor protection, and performance in emerging markets. Journal of Corporate Finance 10 (5), 703-728.

Kohl, M., O'Brien, P., 1998. The macroeconomics of ageing, pensions and savings: A survey. economic department working paper no. 200. OECD, Paris.

Lakonishok, J., Shleifer, A., Vishny, R.W., 1992. The impact of institutional trading on stock prices. Journal of Financial Economics 32 (1), 23-43.

Levine, R., Zervos, S., 1998. Stock markets, banks, and economic growth. The American Economic Review 88 (3), 537-558.

Li, G., 2008. China's stock market: Inefficiencies and institutional implications. China \& World Economy 16 (6), 81-96.

Lim, K.P., Brooks, R.D., 2006. The evolving and relative efficiencies of stock markets: Empirical evidence from rolling bicorrelation tests statistics. SSRN working paper. Available at http://ssrn.com/abstract $=931071$.

Lo, A.W., 2004. The adaptive markets hypothesis. Journal of Portfolio Management 30, 15-29.

Lo, A.W., 2005. Reconciling efficient markets with behavioural finance: The adaptive markets hypothesis. Journal of Investment Consulting 7 (2), 21-44.

Lo, A.W., MacKinlay, A.C., 1988. Stock market prices do not follow random walks: Evidence from a simple specification test. The Review of Financial Studies 1 (1), $41-66$.
Meng, C., Pfau, W.D., 2010. The role of pension funds in capital market development. In: National Graduate Institute for policy studies (GRIPS) discussion papers 10-17. GRIPS, Tokyo.

Ministerial Decree 166, 2014. Decreto 2 settembre 2014, n. 166. Ministero dell'Economia e delle Finanze, Italy.

Ministerial Decree 703, 1996. Decreto 21 novembre 1996, n. 703. Ministero del Tesoro, Italy.

Nawrocki, D., Viole, F., 2014. Behavioral finance in financial market theory, utility theory, portfolio theory and the necessary statistic: A review. Journal of Behavioral and Experimental Finance 2, 10-17.

Newey, W.K., D.W., K., 1987. A simple positive de_nite heteroscedasticity and autocorrelation consistent covariance matrix. Econometrica 55, 703-705.

Norden (Nordic Centre for Welfare and Social Issues), 2013. Focus on the Nordic welfare model. Nordic Centre for Welfare and Social Issues Working paper. In: http:// www.nordicwelfare.org/PageFiles/7117/Nordic_Welfare_Model_Web.pdf.

OECD, 2008. Private pensions outlook 2008 OECD. OECD.

OECD, 2012. OECD pensions outlook 2012. OECD.

OECD, 2015. Pension markets in focus. OECD (http://www.oecd.org).

Popova, Y., Kozhevnikova, M., 2013. Interdependence of HDI and budget redistribution within the Scandinavian and continental social models. Economics and Management 18 (3), 562-575.

Poterba, J., 1998. Population age structure and asset returns: An empirical investigation. NBER working paper 6774.

Poterba, J., 2004. the impact of population ageing on financial markets, National Bureau of economic research working paper 10851 .

Reisen, H., Bailliu, J., 1997. Do funded pensions contribute to higher aggregate savings; a cross country analysis. OECD development Centre technical papers no. 130

Rezk, E., Irace, M., Ricca, V., 2009. Pension funds' contribution to the enhancement of aggregate private saving: A panel data analysis for emerging economies. working paper. (Available at SSRN:http://ssrn.com/abstract $=1992440$ or http://dx.doi.org/ 10.2139/ssrn.1992440)

Rocholl, J., Niggemann, T., 2010. Pension funding and capital market development. working paper. ESMT.

Sapir, A., 2006. Globalization and the reform of European social models. Journal of Common Market Studies 44 (2), 369-390.

Schmidt-Hebbel, K., 1999. Does pension reform really spur productivity, saving and growth. The World Bank.

Sengoku, M. 2004. Emerging eastern European welfare states: A variant of the "European" welfare model. In Slavic Eurasia's integration into the world economy and community. Edited by S. Tabata and A. Iwashita: (Sapporo).

Thomas, A., Spataro, L., Mathew, N., 2014. Pension funds and stock market volatility: An empirical analysis of OECD countries. Journal of Financial Stability $11,92-103$

Tuyon, J., Ahmad, Z., 2016. Behavioural finance perspectives on Malaysian stock market efficiency. Borsa Istanbul Review 16 (1), 43-61.

Urquhart, A., Hudson, R., 2013. Efficient or adaptive markets? Evidence from major stock markets using very long run historic data. International Review of Financial Analysis 28, 130-142.

Vittas, D., 1996. Pension funds and capital markets: Investment regulation, financial innovation, and governance. World Bank, World Bank, Washington, DC.

Vo, X.V., 2015. Foreign ownership and stock return volatility-Evidence from Vietnam. Journal of Multinational Financial Management 30, 101-109.

Vo, X.V., 2016. Does institutional ownership increase stock return volatility? Evidence from Vietnam. International Review of Financial Analysis 45, 54-61.

Walker, E., Lefort, F., 2002. Pension reform and capital markets: Are there any (hard)links?. Revista ABANTE 5 (2), 77-149.

Wermers, R., 1999. Mutual fund herding and the impact on stock prices. The Journal of Finance 54 (2), 581-622.

Zeng, Y., 2016. Institutional investors: Arbitrageurs or rational trend chasers. International Review of Financial Analysis 45, 240-262. 